\title{
Mass Spectral Characterization of Tetracyclines by Electrospray Ionization, H/D Exchange, and Multiple Stage Mass Spectrometry
}

\author{
Amin M. Kamel and Hassan G. Fouda \\ Department of Drug Metabolism, Pfizer Global Research and Development, Groton Laboratories, Groton, \\ Connecticut, USA
}

Phyllis R. Brown

Department of Chemistry, University of Rhode Island, Kingston, Rhode Island, USA

Burnaby Munson

Department of Chemistry and Biochemistry, University of Delaware, Newark, Delaware, USA

Electrospray ionization (ESI) and collisionally induced dissociation (CID) mass spectra were obtained for five tetracyclines and the corresponding compounds in which the labile hydrogens were replaced by deuterium by either gas phase or liquid phase exchange. The number of labile hydrogens, $x$, could easily be determined from a comparison of ESI spectra obtained with $\mathrm{N}_{2}$ and with $\mathrm{ND}_{3}$ as the nebulizer gas. CID mass spectra were obtained for $[\mathrm{M}+\mathrm{H}]^{+}$and $[\mathrm{M}-\mathrm{H}]^{-}$ions and the exchanged analogs, $\left[\mathrm{M}\left(\mathrm{D}_{x}\right)+\mathrm{D}\right]^{+}$and $\left[\mathrm{M}\left(\mathrm{D}_{x}\right)-\mathrm{D}\right]^{-}$, and produced by ESI using a Sciex API-III ${ }^{\text {lus }}$ and a Finnigan LCQ ion trap mass spectrometer. Compositions of product ions and mechanisms of decomposition were determined by comparison of the $\mathrm{MS}^{N}$ spectra of the un-deuterated and deuterated species. Protonated tetracyclines dissociate initially by loss of $\mathrm{H}_{2} \mathrm{O}\left(\mathrm{D}_{2} \mathrm{O}\right)$ and $\mathrm{NH}_{3}\left(\mathrm{ND}_{3}\right)$ if there is a tertiary $\mathrm{OH}$ at C-6. The loss of $\mathrm{H}_{2} \mathrm{O}\left(\mathrm{D}_{2} \mathrm{O}\right)$ is the lower energy process. Tetracyclines without the tertiary $\mathrm{OH}$ at C-6 lose only $\mathrm{NH}_{3}\left(\mathrm{ND}_{3}\right)$ initially. $\mathrm{MS}^{N}$ experiments showed easily understandable losses of $\mathrm{HDO}, \mathrm{HN}\left(\mathrm{CH}_{3}\right)_{2}, \mathrm{CH}_{3}-\mathrm{N}=\mathrm{CH}_{2}$, and $\mathrm{CO}$ from fragment ions. The major fragment ions do not come from cleavage reactions of the species protonated at the most basic site. Deprotonated tetracyclines had similar CID spectra, with less fragmentation than those observed for the protonated tetracyclines. The lowest energy decomposition paths for the deprotonated tetracyclines are the competitive loss of $\mathrm{NH}_{3}\left(\mathrm{ND}_{3}\right)$ or $\mathrm{HNCO}$ (DNCO). Product ions appear to be formed by charge remote decompositions of species de-protonated at the C-10 phenol. (J Am Soc Mass Spectrom 2002, 13, 543-557) (C) 2002 American Society for Mass Spectrometry

$\mathrm{M}$ ass spectrometry has long been regarded as an important analytical tool in drug metabolism, pharmacokinetics, and biochemical toxicology. However, with the commercial availability of new ionization methods, such as atmospheric pressure ionization (API) and ESI, and the combination of liquid chromatography-massspectrometry(LC-MS), massspectrometry is now a truly indispensable technique in pharmaceutical science. LC-MS systems equipped with electrospray, ionspray, or heated nebulizer interfaces have been utilized extensively in metabolic studies of foreign compounds because of their very high sensitivity, their compatibility with reverse-phase chromatog-

Published online April 2, 2002

Address reprint requests to Dr. A. M. Kamel, Department of Drug Metabolism, Pfizer Global Research and Development, Groton Laboratories, Eastern Point Road, Groton, CT 06340, USA. E-mail: amin_m_kamel@ groton.pfizer.com raphy, and their applicability to structural elucidation of polar and thermally labile drug conjugates.

The most widely used approach for obtaining structural information on compounds analyzed by the soft ionization methods mentioned above has been through collisionally induced decompositions (CID) of protonated molecules, $[\mathrm{M}+\mathrm{H}]^{+}$, or deprotonated molecules, $[\mathrm{M}-\mathrm{H}]^{-}$. CID studies are employed in structural characterization of compounds because the collision process is an effective means of introducing sufficient internal energy into the protonated or deprotonated molecules for extensive fragmentation. Tandem mass spectrometry also allows an unambiguous assignment of reactant/product sequences free of interferences that may be present in complex biological fluids or reaction mixtures.

The determination of the number of replaceable hydrogens, such as $\mathrm{OH}, \mathrm{COOH}, \mathrm{NH}$, or $\mathrm{SH}$, by simple 


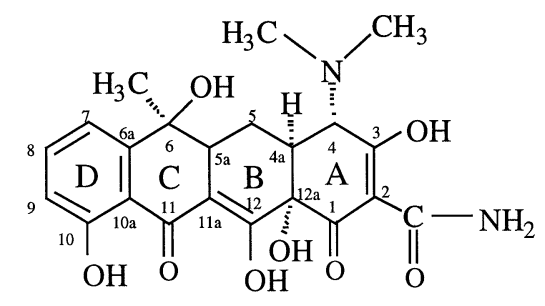<smiles>CN(C)[C@H]1C(O)=C(C(N)=O)C(=O)[C@]2(O)C(O)=C3C(=O)c4c(O)cccc4[C@@](C)(O)C3[C@H](O)[C@H]12</smiles>

Oxytetracycline<smiles>C=C1c2cccc(O)c2C(=O)C2=C(O)[C@]3(O)C(=O)C(C(N)=O)=C(O)[C@H](N(C)C)[C@H]3[C@H](O)C12</smiles>

Methacycline<smiles>CN(C)[C@H]1C(O)=C(C(N)=O)C(=O)[C@]2(O)C(O)=C3C(=O)c4c(O)ccc(Cl)c4[C@@](C)(O)C3C[C@H]12</smiles>

Chlorotetracycline<smiles>CN(C)c1ccc(O)c2c1CC1CC3[C@H](N(C)C)C(O)=C(C(N)=O)C(=O)[C@]3(O)C(O)=C1C2=O</smiles>

Minocycline

Figure 1. Structures of tetracyclines

exchange of the sample in the presence of heavy water, $\mathrm{D}_{2} \mathrm{O}$, is widely used in mass spectrometry. Although the incorporation of deuterium can be effectively carried out by a variety of preparative liquid and gas chromatographic procedures, the direct combination of LC with MS obviates the necessity of isolation of individual components. In addition, the coupling permits direct comparison of mass spectra of labeled compounds of a mixture with spectra of unlabeled components obtained in a conventional fashion from a separate chromatographic analysis, but under essentially identical mass spectrometric conditions.

The chemical incorporation of deuterium followed by ionization has played a major role in the structural characterization of molecules, in gaining information on the mechanisms of chemical or biological reactions, and in the interpretation of mass spectra [1-7]. Many ionization methods have been used: Electron ionization (EI) [1], chemical ionization (CI) [8-10], fast atom bombardment (FAB) [11-13], thermospray [14, 15], particle beam [15], and electrospray ionization (ESI) [3, 16-25]. The exchange of hydrogen by deuterium has been used extensively in the study of gas phase ion molecule reactions [26]. Isotopic exchange reactions in CI systems are normally carried out in solution before the sample is introduced into the mass spectrometer but exchange can also occur in the ion source of the mass spectrometer $[26,27]$.
Hemling and co-workers developed a simple method for gas phase hydrogen/deuterium exchange that required only minor changes in the plumbing of a Sciex API-III ${ }^{\text {plus }}$ ion spray source. Extensive exchange of active hydrogens was achieved by replacing either all or part of the nebulizer or curtain gas with a deuterated exchange agent like $\mathrm{ND}_{3}$. The authors reported gas phase H/D exchange of ions produced by ESI that compared favorably with desorption chemical ionization and FAB exchange methods [28].

The tetracyclines are an important family of antibiotics. Structural modifications of tetracyclines play critical roles in their functions, both chemical modification and xenobiotic alteration. Nine closely related compounds-tetracycline, rolitetracycline, oxytetracycline, chlortetracycline, demeclocycline, meclocycline, methacycline, doxycycline, and minocycline-are widely used in human and veterinary medicine. The tetracyclines have been monitored by high pressure liquid chromatography (HPLC) with ultraviolet or fluorescence detection [29], thin layer chromatography and LC/FAB/MS [30, 31], LC/particle beam/MS [32], and ESI/MS [3340]. Mass spectrometric techniques for the analysis of tetracycline antibiotics in foods have been reviewed [41]. Some CID spectra of tetracyclines have been reported previously $[42,43]$. 

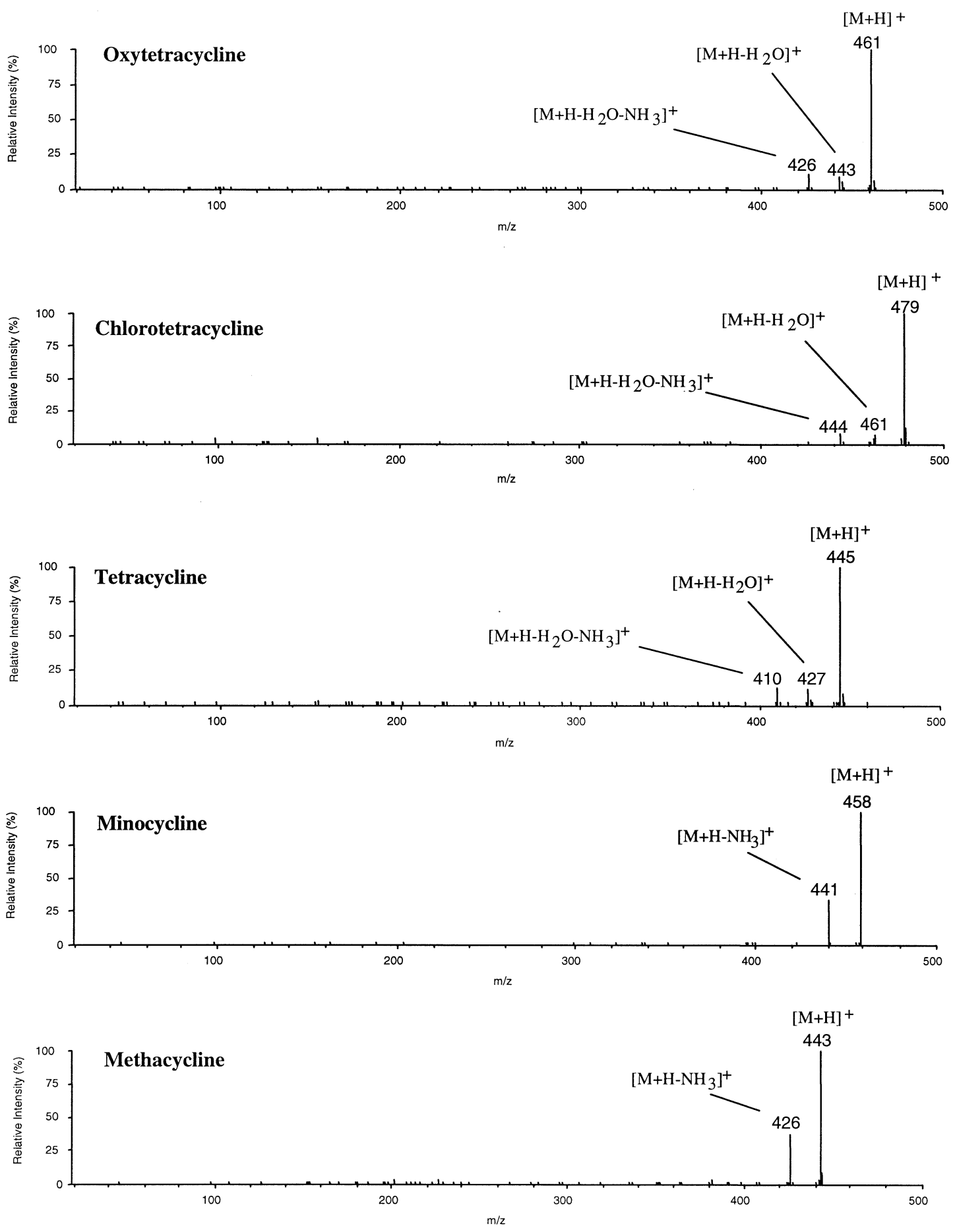

Figure 2. CID product ion spectra of $[\mathrm{M}+\mathrm{H}]^{+}$ions of Tetracyclines at low collision energy (CE) of $5 \mathrm{eV}$ using a Sciex API III ${ }^{\text {lus }}$ quadrupole mass spectrometer.

The present study was undertaken to determine structures and mechanisms of formation of principal fragment ions in the ESI mass spectra of five tetracyclines. Hydrogen/deuterium exchange and multiple stage mass spectrometry in positive and negative ionization modes were utilized to determine fragmentation processes. Knowledge of fragmentation mechanisms for CID spectra of $[\mathrm{M}+\mathrm{H}]^{+}$and $[\mathrm{M}-\mathrm{H}]^{-}$ions for tetracyclines can aid in the characterization of metabolites of the tetracyclines and related compounds.

\section{Experimental}

\section{Chemicals and Materials}

Five tetracyclines, shown in Figure 1 with the numbering system for tetracycline, were purchased from Sigma 

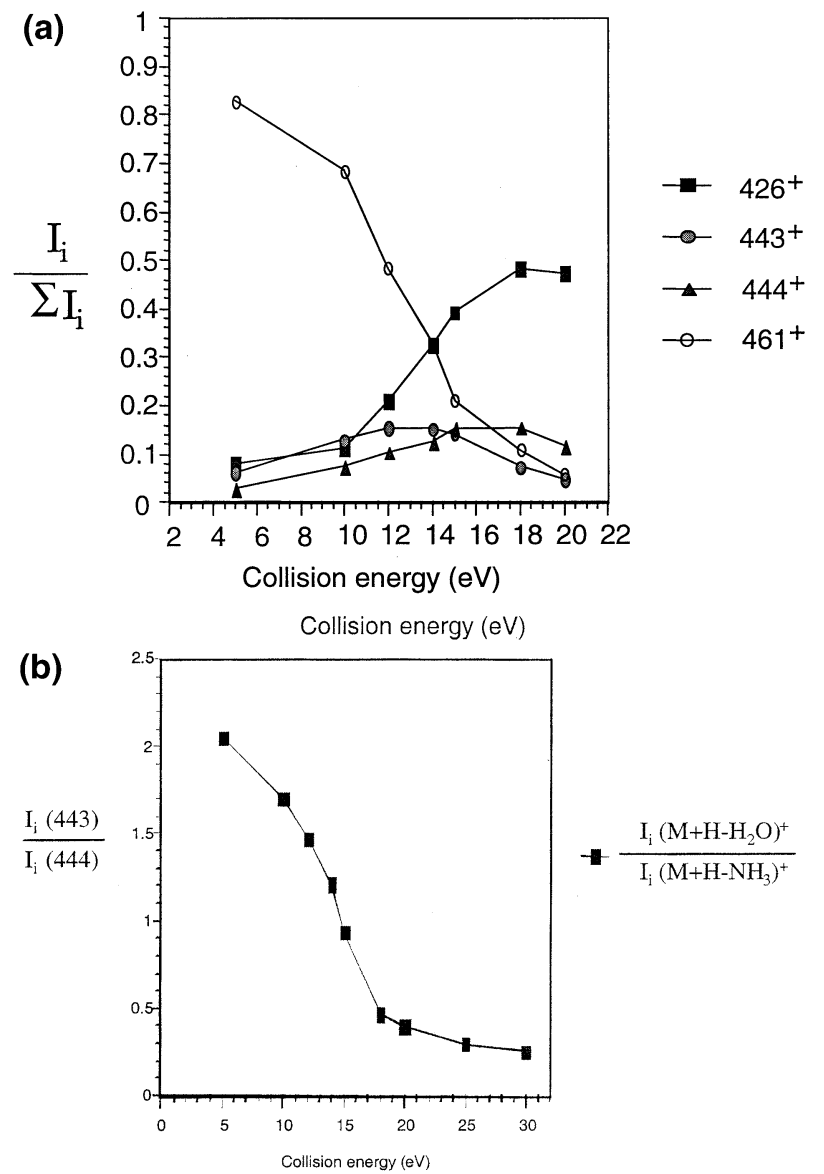

Figure 3. (a) Intensities of fragment product ions from the reaction of protonated oxytetracycline with argon (Ar) in the collision chamber of a triplequadrupole mass spectrometer as a function of collision energy $\left(\mathrm{I}_{\mathrm{i}}\right.$ is the ion intensity of a fragment ion and $I_{i}$ is the sum of all fragment ions). (b) Ratio of the fragment ion $(\mathrm{m} / \mathrm{z} 443)$ to the fragment ion $(\mathrm{m} / \mathrm{z} 444)$ vs collision energy from the reaction of protonated oxytetracycline with argon (Ar).

Chemical Co. (St. Louis, MO). Methanol and deionized water (HPLC grade) were obtained from J. T. Baker (Phillipsburg, NJ). Glacial acetic acid and ammonium hydroxide (HPLC grade) were obtained from Fisher (Fair Lawn, NJ). Deuterated ammonia $\left(99+\% \mathrm{ND}_{3}\right)$ was obtained from Cambridge Isotopes Laboratory (Andover, MA). The other deuterated compounds ( $\geq 99 \%$ D) were obtained from Aldrich Chemical Co. (Milwaukee, WI).

\section{Hydrogen/Deuterium Exchange}

Both gas phase and solution phase H/D exchange were used to determine fragmentation pathways of $[\mathrm{M}+$ $\mathrm{H}]^{+}$and $[\mathrm{M}-\mathrm{H}]^{-}$ions of the tetracyclines. A modification was made to the Sciex API-III ${ }^{\text {lus }}$ electrospray source to allow gas phase H/D exchange in the nebulization region, as described by Hemling et al. [28]. This modification involved the addition of a valve prior to the nebulizer for rapid switching from the $\mathrm{N}_{2}$ normally used for nebulization to $\mathrm{ND}_{3}$ during loop injection analysis of a sample. Normal spectra and H/D exchanged

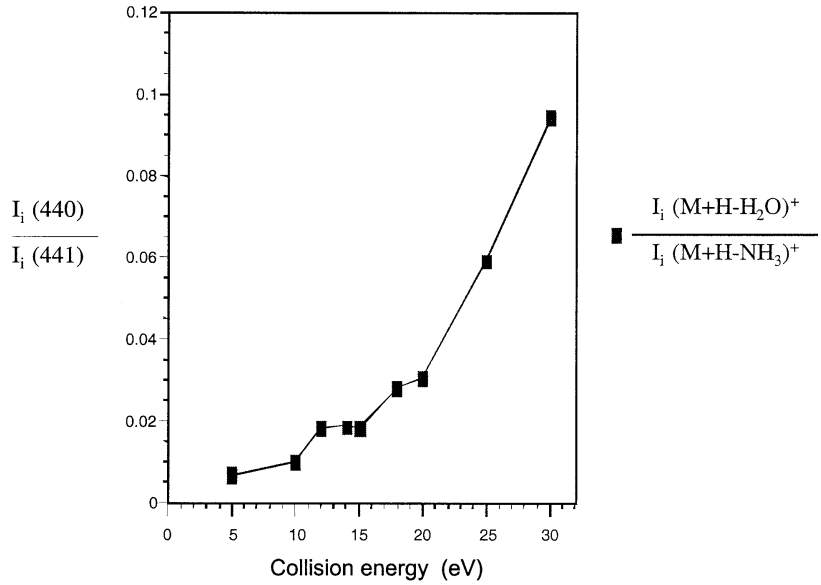

Figure 4. Ratio of the fragment ion $(\mathrm{m} / \mathrm{z} 440)$ to the fragment ion $(\mathrm{m} / \mathrm{z} 441)$ vs collision energy from the reaction of protonated minocycline with argon (Ar).

spectra for a single injection were obtained by averaging several (5-10) spectra with $\mathrm{N}_{2}$ as the nebulizer gas and then switching to $\mathrm{ND}_{3}$ for several scans and then switching to $\mathrm{N}_{2}$ for subsequent experiments. Both partially exchanged and fully exchanged species were observed. However, for these compounds it was easy to determine the number of exchangeable hydrogens.

Solution phase $\mathrm{H} / \mathrm{D}$ exchange was achieved by dissolving samples in $\mathrm{D}_{2} \mathrm{O} / \mathrm{CH}_{3} \mathrm{OD}$ with $1 \%$ $\mathrm{CD}_{3} \mathrm{COOD}$ for positive ion spectra and $50 \mathrm{mM} \mathrm{ND}_{4} \mathrm{OD}$ for negative ion spectra.

\section{Sample Preparation and Introduction}

Each tetracycline was dissolved in $\mathrm{H}_{2} \mathrm{O} / \mathrm{CH}_{3} \mathrm{OH}(1 / 1$ by volume) to make a $20 \mu \mathrm{g} / \mathrm{mL}$ solution with $1 \%$ $\mathrm{CH}_{3} \mathrm{COOH}$ or $50 \mathrm{mM} \mathrm{NH} \mathrm{NH}_{4} \mathrm{OH}$ for positive or negative ion spectra, respectively. Recent work from this laboratory showed that $1 \% \mathrm{CH}_{3} \mathrm{COOH}$ or $50 \mathrm{mM} \mathrm{NH} \mathrm{NH}_{4} \mathrm{OH}$ significantly increased the sensitivities of tetracyclines and antiviral agents in the positive or negative ionization mode, respectively [40,44]. For solution phase $\mathrm{H} / \mathrm{D}$ exchange, each tetracycline was dissolved in $\mathrm{D}_{2} \mathrm{O} / \mathrm{CH}_{3} \mathrm{OD}(1 / 1$ by volume) to make a make a 20 $\mu \mathrm{g} / \mathrm{mL}$ solution with $1 \% \mathrm{CD}_{3} \mathrm{COOD}$ for positive ion spectra or $50 \mathrm{mM} \mathrm{ND} \mathrm{m}_{4} \mathrm{OD}$ for negative ion spectra. Samples were infused into the electrospray interface using a Harvard syringe pump (South Natick, MA) at a flow rate of $2 \mu \mathrm{L} / \mathrm{min}$.

\section{Mass Spectrometry}

Mass spectral analyses were performed with a Sciex API-III ${ }^{\text {plus }}$ triple quadrupole mass spectrometer with a mass range to $2400 \mathrm{D}$ (Thornhill, Ontario, Canada). The mass spectrometer was equipped with an ion spray interface with a nebulizer gas pressure $\left(\mathrm{N}_{2}\right)$ of 60 psi. The nitrogen curtain gas was adjusted to a flow rate of $1.2 \mathrm{~L} / \mathrm{min}$. Positive or negative ions formed at atmospheric pressure were sampled into the quadrupole 

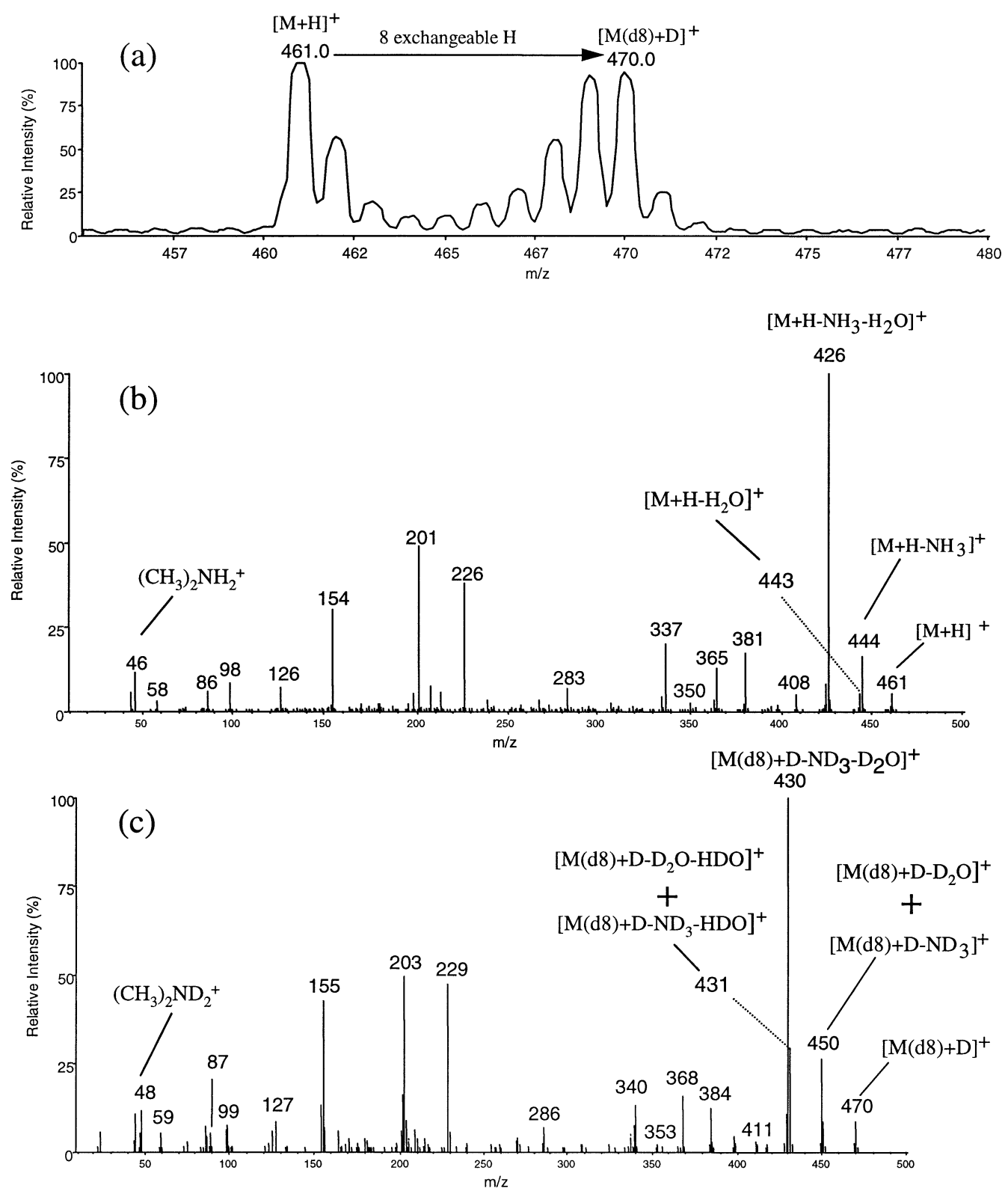

Figure 5. Positive ion ESI mass spectra of oxytetracycline (MW = 460): (a) total ion curent (TIC) showing both $[\mathrm{M}+\mathrm{H}]^{+}$and $[\mathrm{M}(\mathrm{d} 8)+\mathrm{D}]^{+}$in a single experiment $(\mathrm{b})$ CID product ion spectrum of $[\mathrm{M}+\mathrm{H}]^{+}$at $\mathrm{m} / \mathrm{z} 461$ at a collision energy of $25 \mathrm{eV}$ (c) CID porduct ion spectrum of the fully exchanged $[\mathrm{M}(\mathrm{d} 8)+\mathrm{D}]^{+}$at $\mathrm{m} / \mathrm{z} 470$ at a collision energy of $25 \mathrm{eV}$. Deuteration was achieved by nebulizer $\mathrm{ND}_{3}$ gas phase $\mathrm{H} / \mathrm{D}$ exchange on a Sciex API-III ${ }^{+}$triple quadrupole mass spectrometer.

mass filter via a 0.0045 in diameter aperture. CID studies were performed with Ar at a thickness of $\sim 2 \times$ $10^{15}$ atoms $/ \mathrm{cm}^{2}$ with collision energies of $5-25 \mathrm{eV}$. Collisions occurred in Q2. Unit mass resolution was established with a $2 \mathrm{~ms}$ dwell time and the signal was averaged over 10 scans.

An ion trap, Finnigan LCQ (Finnigan MAT, San Jose, CA), was used for experiments involving multiple stages of decomposition, $\mathrm{MS}^{N}$, at a spray voltage of $\sim 3.5 \mathrm{keV}$ with a current of $2 \mu \mathrm{amp}$. The capillary was maintained at $200^{\circ} \mathrm{C}$ with an offset voltage of $5 \mathrm{~V}$. CID spectra are the average of 5-15 scans, depending on the relative abundance of the precursor ions. The mass width for isolation prior to the CID experiments was 2 $\mathrm{Da}$. The relative collision energy was set at $10-25 \%$ (arbitrary units). In these experiments the protonated or deprotonated tetracycline was subjected to CID to produce a first set of fragment ions, MS/MS or $\mathrm{MS}^{2}$. Subsequently one of the fragment ions from $[\mathrm{M}+\mathrm{H}]^{+}$ or $[\mathrm{M}-\mathrm{H}]^{-}$was isolated and decomposed to give the next set of fragment ions, $\mathrm{MS}^{3}$, and the process was continued. 


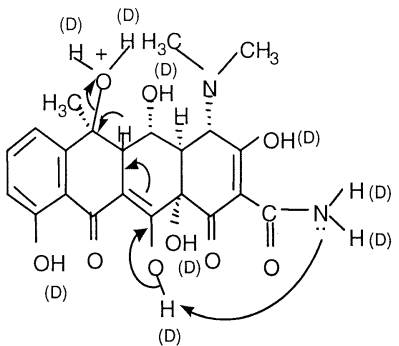

$461(470)$

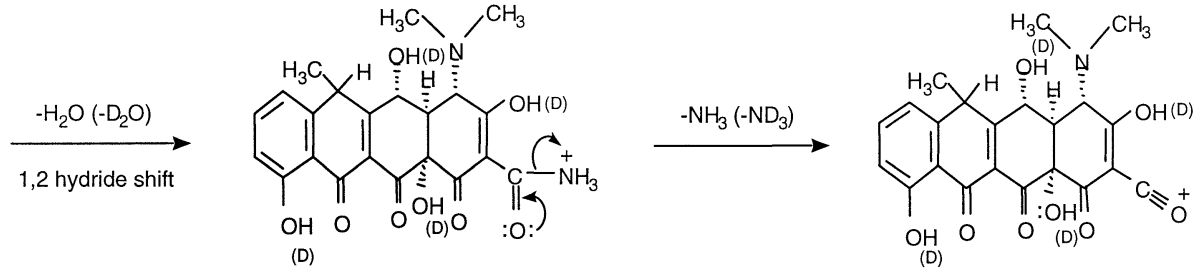

$443(450)$

426(430)

Scheme 1. Proposed reactions and CID fragmentation pathways mechanisms of protonated oxytetracycline and its fragment ions determined from both $\mathrm{H} / \mathrm{D}$ exchange patterns and ion trap $\mathrm{MS}^{\mathrm{N}}$ experiments assuming a proton transfer to the C-6 hydroxyl group. Numbers in parentheses refer to deuterated fragment ions.

\section{Results and Discussion}

\section{Positive Ions}

The CID spectra of $[\mathrm{M}+\mathrm{H}]^{+}$ions of the tetracyclines obtained at collision energy of $25 \mathrm{eV}$ (lab energy, $\sim 2 \mathrm{eV}$ center of mass energy) contain many fragment ions that can be used for structure confirmation. However, the spectra are much simpler at lower collision energies. The low energy ( $5 \mathrm{eV}$ ) CID mass spectra of five protonated tetracyclines are shown in Figure 2. The spectra of methacycline and minocycline contain only one product ion: The loss of $\mathrm{NH}_{3}$ from $[\mathrm{M}+\mathrm{H}]^{+}$. The low energy CID spectra of the other three compounds (tetracycline, chlortetracycline, and oxytetracycline) are similar and contain $\left[\mathrm{M}+\mathrm{H}-\mathrm{H}_{2} \mathrm{O}\right]^{+},\left[\mathrm{M}+\mathrm{H}-\mathrm{NH}_{3}\right]^{+}$, and $[\mathrm{M}+$ $\left.\mathrm{H}-\mathrm{H}_{2} \mathrm{O}-\mathrm{NH}_{3}\right]^{+}$ions. As was noted previously, the protonated tetracyclines that fragment by loss of water have structures with a tertiary $\mathrm{OH}$ at C-6 $[42,43]$.

Figure 3 shows the effects of collision energy on the lowest energy CID products from $[\mathrm{M}+\mathrm{H}]^{+}$ions of oxytetracycline. Figure $3 a$ shows a rapid decrease in relative abundance of $[\mathrm{M}+\mathrm{H}]^{+}$at $m / z 461$, maxima in the relative abundances of $\left[\mathrm{M}+\mathrm{H}-\mathrm{H}_{2} \mathrm{O}\right]^{+}$at $m / z 443$ and $\left[\mathrm{M}+\mathrm{H}-\mathrm{NH}_{3}\right]^{+}$at $\mathrm{m} / z$ 444, and a rapid increase in the relative abundance of $\left[\mathrm{M}+\mathrm{H}-\mathrm{H}_{2} \mathrm{O}-\mathrm{NH}_{3}\right]^{+}$at $\mathrm{m} / \mathrm{z} 426$ with increasing energy. The maxima with increasing collision energy in the plots of the relative abundance of the primary decomposition products at
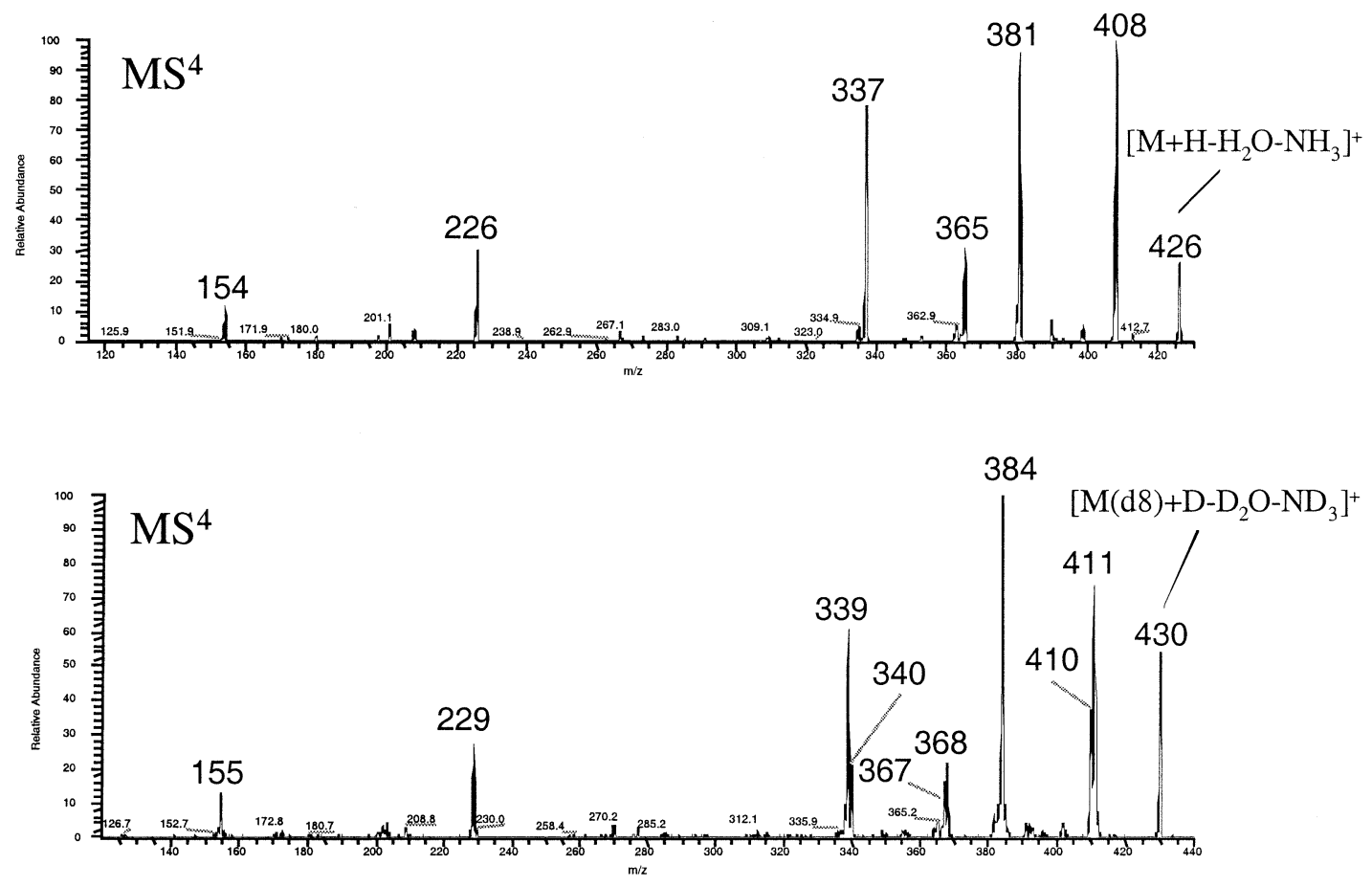

Figure 6. Positive ion ESI mass spectra of oxytetracycline $(\mathrm{MW}=460)$ and its fragment ions: $\mathrm{MS}^{4}$ of fragment ion at $\mathrm{m} / \mathrm{z} 426$ (top) and its corresponding deuterated fragment ion at $\mathrm{m} / \mathrm{z} 430$ (bottom). Deuteration was achieved by solution phase H/D exchange method. MS ${ }^{2}$ and $\mathrm{MS}^{\mathrm{N}}$ experiments were performed on a Finnigan-MAT LCQ ion trap mass spectrometry. 

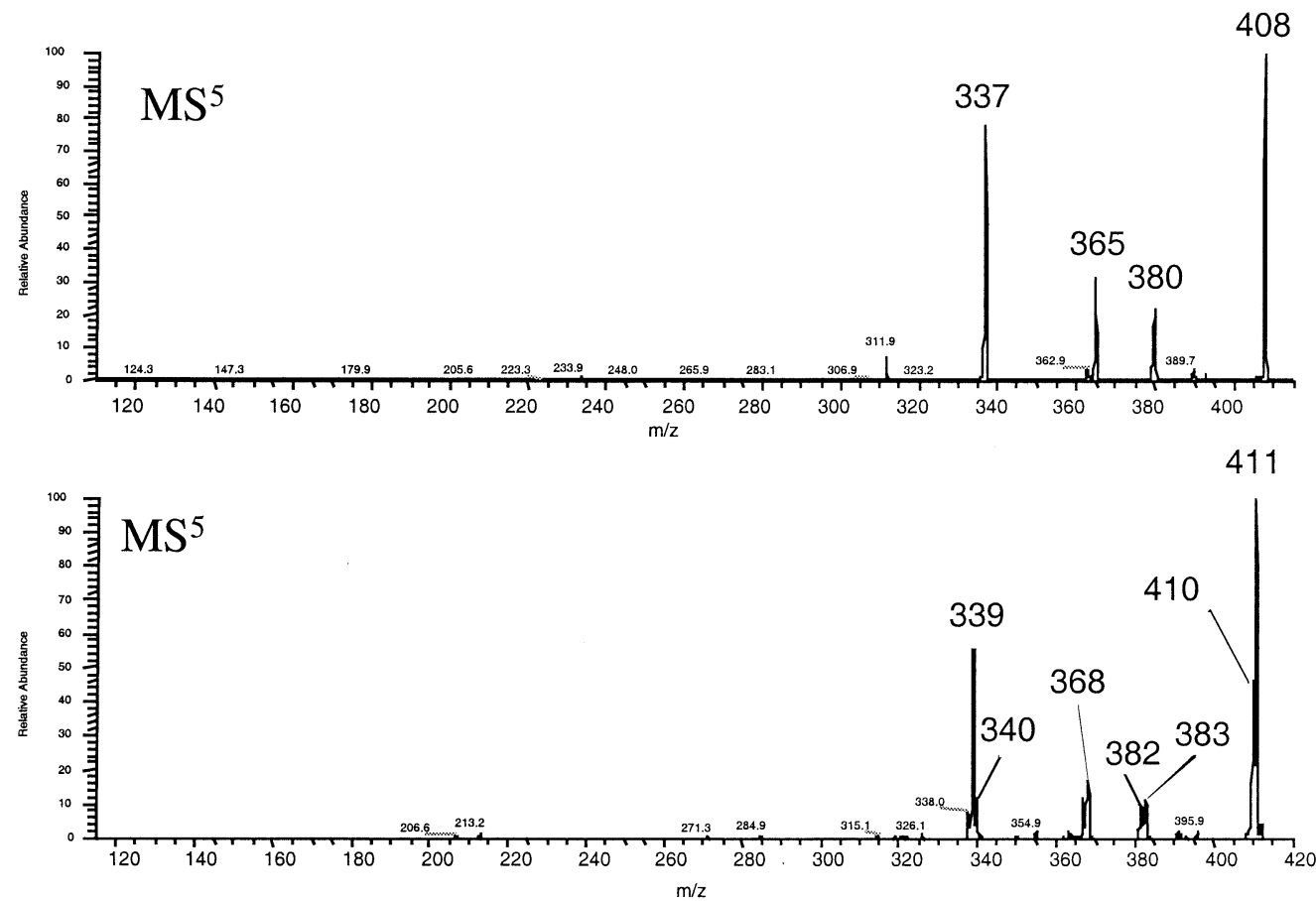

Figure 7. Positive ion ESI mass spectra of oxytetracycline $(\mathrm{MW}=460)$ and its fragment ions: $\mathrm{MS}^{5}$ of fragment ion at $m / z 408$ (top) and its corresponding deuterated fragment ion at $m / z 411$ (bottom). Deuteration was achieved by solution phase H/D exchange method. MS ${ }^{2}$ and $M^{N}{ }^{N}$ experiments were performed on a Finnigan-MAT LCQ ion trap mass spectrometry.

$\mathrm{m} / \mathrm{z} 443$ and 444 (Figure 3a) indicate that these ions decompose to give the ions at $\mathrm{m} / \mathrm{z} 426$.

Figure $3 \mathrm{~b}$ shows the decrease with increasing collision energy of the ratio of product ions, $\mathrm{I}_{\mathrm{i}}(443) /$ $\mathrm{I}_{\mathrm{i}}(444)=\mathrm{I}_{\mathrm{i}}\left(\mathrm{M}+\mathrm{H}-\mathrm{H}_{2} \mathrm{O}\right)^{+} / \mathrm{I}_{\mathrm{i}}\left(\mathrm{M}+\mathrm{H}-\mathrm{NH}_{3}\right)^{+}$. These results show that the loss of water from $[\mathrm{M}+$ $\mathrm{H}^{+}$is the dominant process (a factor of 2 ) at the lowest collision energy and presumably corresponds to the lowest energy decomposition process.

Plots similar to Figures $3 a$ and $b$ were obtained with $[\mathrm{M}+\mathrm{H}]^{+}$ions from tetracycline, $\mathrm{I}_{\mathrm{i}}(427) / \mathrm{I}_{\mathrm{i}}(428)=\mathrm{I}_{\mathrm{i}}(\mathrm{M}+$ $\left.\mathrm{H}-\mathrm{H}_{2} \mathrm{O}\right)^{+} / \mathrm{I}_{\mathrm{i}}\left(\mathrm{M}+\mathrm{H}-\mathrm{NH}_{3}\right)^{+}=3.1 @ 5 \mathrm{eV}$, and from chlorotetracycline, $\mathrm{I}_{\mathrm{i}}(461) / \mathrm{I}_{\mathrm{i}}(462)=\mathrm{I}_{\mathrm{i}}\left(\mathrm{M}+\mathrm{H}-\mathrm{H}_{2} \mathrm{O}\right)^{+} /$ $\mathrm{I}_{\mathrm{i}}\left(\mathrm{M}+\mathrm{H}-\mathrm{NH}_{3}\right)^{+}=0.3 @ 5 \mathrm{eV}$. Subsequent decomposition reactions observed with these two compounds as well: $\left[\mathrm{M}+\mathrm{H}-\mathrm{H}_{2} \mathrm{O}\right]^{+}$ions lost $\mathrm{NH}_{3}$ and $\left[\mathrm{M}+\mathrm{H}-\mathrm{NH}_{3}\right]^{+}$ ions lost $\mathrm{H}_{2} \mathrm{O}$ to give abundant $\left[\mathrm{M}+\mathrm{H}-\mathrm{H}_{2} \mathrm{O}-\mathrm{NH}_{3}\right]^{+}$ ions for tetracycline and for chlortetracycline.

These data indicate competing parallel decomposition reactions for these three protonated tetracyclines:

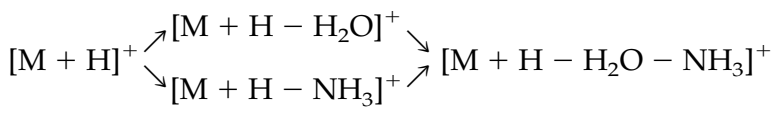

Figure 4 shows a plot of data from similar experiments with minocycline: An increase with increasing collision energy for the ratio, $\mathrm{I}_{\mathrm{i}}(440) / \mathrm{I}_{\mathrm{i}}(441)=\mathrm{I}_{\mathrm{i}}\left(\mathrm{M}+\mathrm{H}-\mathrm{H}_{2} \mathrm{O}\right)^{+}$/ $\mathrm{I}_{\mathrm{i}}\left(\mathrm{M}+\mathrm{H}-\mathrm{NH}_{3}\right)^{+}$. Only a very small water loss is observed. A similar plot is observed for the collision energy dependence of products of $\mathrm{MH}^{+}$ions from metha- cycline. The ratio of product ions can be extrapolated to zero at zero collision energy; hence, for these two tetracyclines (without a tertiary $\mathrm{OH}$ at C-6), the lowest energy CID process is the loss of $\mathrm{NH}_{3}$ from $\mathrm{MH}^{+}$.

MS/MS experiments with an ion trap show $\left[\mathrm{M}+\mathrm{H}-\mathrm{H}_{2} \mathrm{O}\right]^{+}$at $m / z 443$ as essentially the only decomposition product from $[\mathrm{M}+\mathrm{H}]^{+}$at $\mathrm{m} / \mathrm{z} 461$ from oxytetracycline: $\mathrm{I}_{\mathrm{i}}(444) / \mathrm{I}_{\mathrm{i}}(443) \leq 0.05$. Under comparable collision conditions, $\left[\mathrm{M}\left(\mathrm{D}_{8}\right)+\mathrm{D}\right]^{+}$at $\mathrm{m} / \mathrm{z}$ 470 from oxytetracycline that has undergone liquid phase $\mathrm{H} / \mathrm{D}$ exchange decomposes almost exclusively to $\left[\mathrm{M}\left(\mathrm{D}_{8}\right)+\mathrm{D}-\mathrm{D}_{2} \mathrm{O}\right]^{+}$at $m / z 450: \mathrm{I}_{\mathrm{i}}(451) / \mathrm{I}_{\mathrm{i}}(450) \leq$ 0.1 . There is essentially no loss of HDO from OD with $\mathrm{H}$ bonded to $\mathrm{C}-5 \mathrm{a}$ via charge remote fragmentation of $\mathrm{N}$-protonated ions [45]. The rigid structure of the four rings of the tetracyclines indicate that loss of $\mathrm{D}_{2} \mathrm{O}$ from the OD group at C-6 and any other OD group is very unlikely.

Loss of water from a species protonated on the hydroxyl group at C-6 is a reasonable process. However, this hydroxyl group should not be the most basic site of the molecule that one would expect to be protonated in $[\mathrm{M}+\mathrm{H}]^{+}$ions produced by ESI. Proton affinities or basicities of complex molecules like the tetracyclines are not known. However, one can estimate the gas phase basicity (GB) of a site from gas phase basicities of model compounds: The higher GB, the more basic the site and the greater the equilibrium population of species protonated at that site [46].

The basicity of the dimethylamino group at C-4 


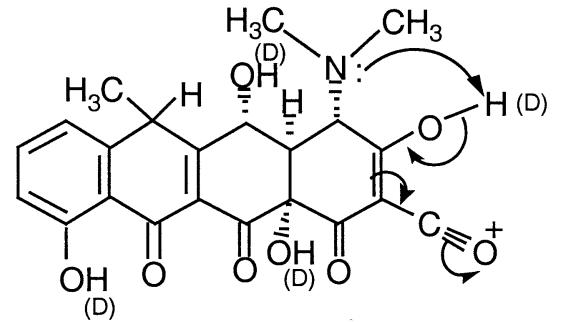

426(430)

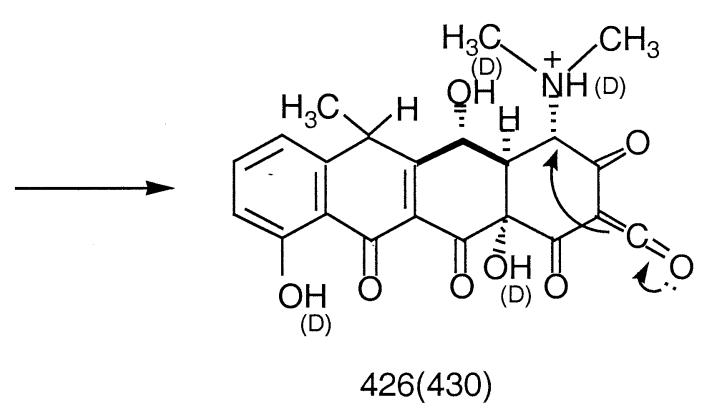
$-\mathrm{HN}(\mathrm{Me})_{2}\left(-\mathrm{DN}(\mathrm{Me})_{2}\right) \mid$ (Favorskii rearrangement)

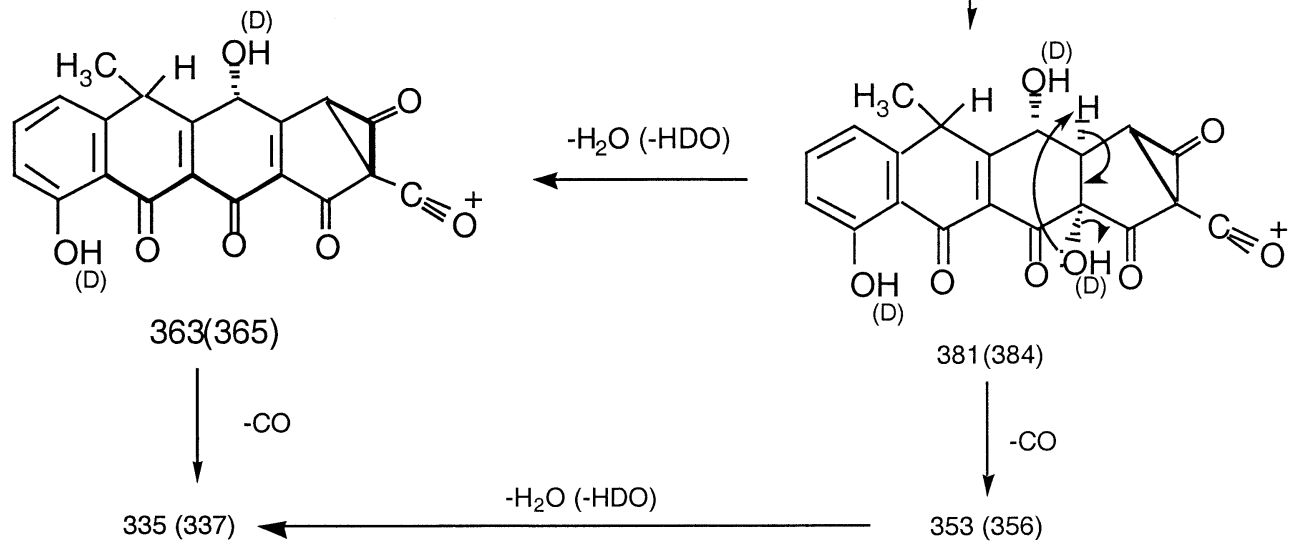

Scheme 2. Proposed CID fragmentation pathways mechanisms of the fragment ion at $\mathrm{m} / \mathrm{z}=426$ from protonated Oxytetracycline determined from both $\mathrm{H} / \mathrm{D}$ exchange patterns and ion trap $\mathrm{MS}^{\mathrm{N}}$ experiments. Numbers in parentheses refer to deuterated fragment ions.

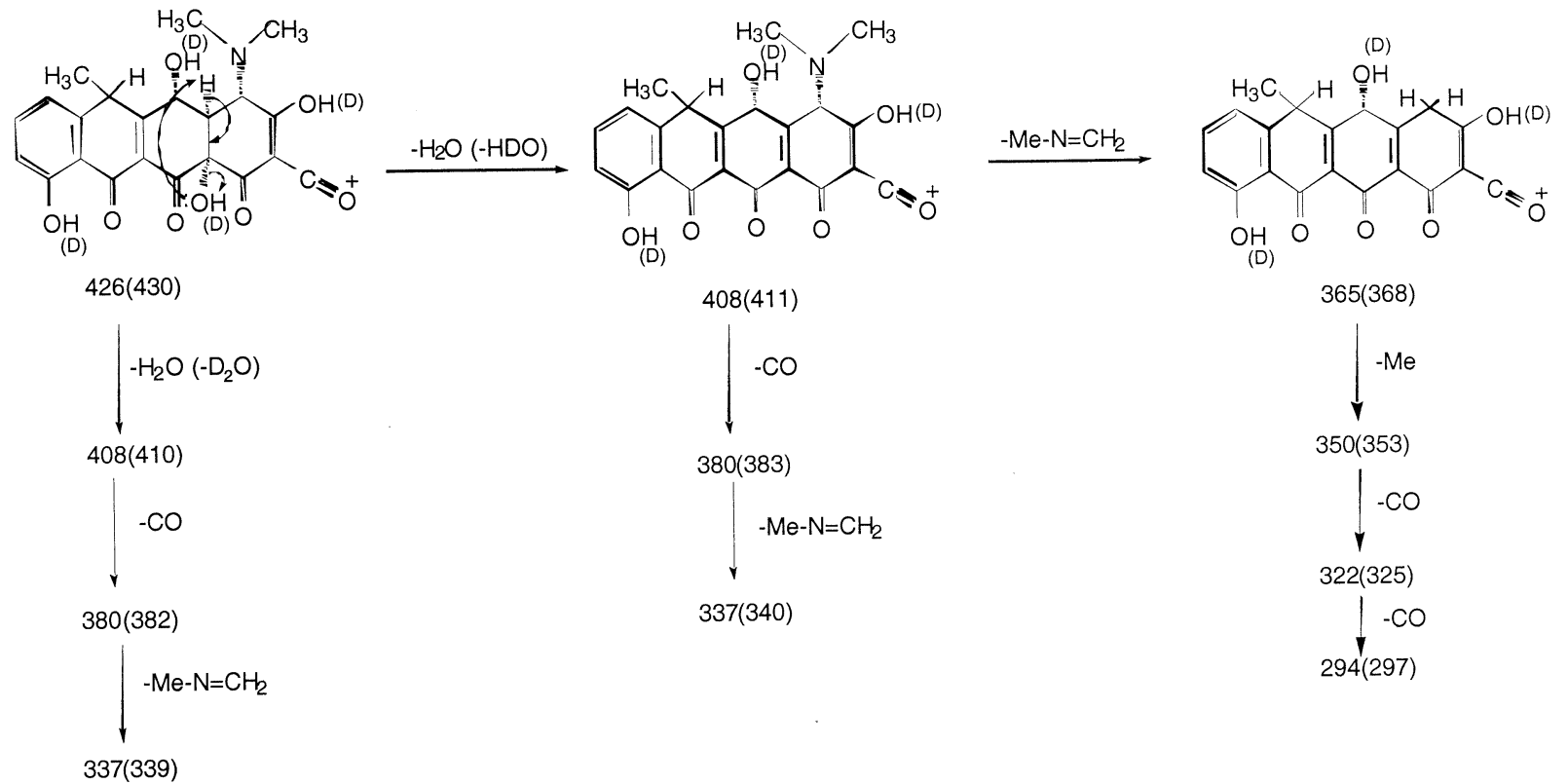

Scheme 3. Proposed CID fragmentation pathways mechanisms of the fragment ion at $\mathrm{m} / \mathrm{z}=426$ from protonated oxytetracycline determined from both $\mathrm{H} / \mathrm{D}$ exchange patterns and ion trap $\mathrm{MS}^{\mathrm{N}}$ experiments. Numbers in parentheses refer to deuterated fragment ions. 
Table 1. Principal dissociation products of protonated tetracyclines

\begin{tabular}{|c|c|c|c|}
\hline Product Ion & $m / z$ & $\begin{array}{l}\text { Deuterated } \\
\text { product ion }\end{array}$ & $\begin{array}{l}\text { Deuterated } \\
\quad \mathrm{m} / \mathrm{z}\end{array}$ \\
\hline \multicolumn{4}{|c|}{ Tetracycline $\left(\mathrm{MW}=444,[\mathrm{M}+\mathrm{H}]^{+}=445,[\mathrm{M}(\mathrm{d} 7)+\mathrm{D}]^{+}=453\right)$} \\
\hline $445-\mathrm{H}_{2} \mathrm{O}$ & 427 & $453-\mathrm{D}_{2} \mathrm{O}$ & 433 \\
\hline $427-\mathrm{NH}_{3}$ & 410 & $433-N_{3}$ & 413 \\
\hline $410-\mathrm{H}_{2} \mathrm{O}$ & 392 & $433-\mathrm{HDO}$ & 394 \\
\hline $392-\mathrm{CO}$ & 364 & $394-\mathrm{CO}$ & 366 \\
\hline $392-\mathrm{CH}_{3}$ & 377 & $394-\mathrm{CH}_{3}$ & 379 \\
\hline $392-\mathrm{H}_{3} \mathrm{C}-\mathrm{N}=\mathrm{CH}_{2}$ & 349 & $394-\mathrm{H}_{3} \mathrm{C}-\mathrm{N}=\mathrm{CH}_{2}$ & 351 \\
\hline $349-\mathrm{CO}$ & 321 & $351-\mathrm{CO}$ & 323 \\
\hline $410-\left(\mathrm{H}_{3} \mathrm{C}\right)_{2}-\mathrm{NH}$ & 365 & $413-\left(\mathrm{H}_{3} \mathrm{C}\right)_{2}-\mathrm{ND}$ & 367 \\
\hline $365-\mathrm{CO}$ & 337 & $367-\mathrm{CO}$ & 339 \\
\hline $410-\mathrm{CO}$ & 382 & $413-\mathrm{CO}$ & 385 \\
\hline $445-\mathrm{NH}_{3}-274$ & 154 & $453-N_{3}-274$ & 155 \\
\hline $154-\mathrm{CO}$ & 126 & $155-\mathrm{CO}$ & 127 \\
\hline $126-\mathrm{CO}$ & 98 & 127 - CO & 99 \\
\hline $126-\mathrm{C}_{3} \mathrm{O}_{2}$ & 58 & $127-\mathrm{C}_{3} \mathrm{O}_{2}$ & 59 \\
\hline \multicolumn{4}{|c|}{$\begin{array}{l}\text { Oxytetracycline }\left(\mathrm{MW}=460,[\mathrm{M}+\mathrm{H}]^{+}=461,[\mathrm{M}(\mathrm{d} 8)+\mathrm{D}]^{+}=\right. \\
470)\end{array}$} \\
\hline $461-\mathrm{H}_{2} \mathrm{O}$ & 443 & $470-\mathrm{D}_{2} \mathrm{O}$ & 450 \\
\hline $443-\mathrm{NH}_{3}$ & 426 & $450-N_{3}$ & 430 \\
\hline $426-\mathrm{H}_{2} \mathrm{O}$ & 408 & $430-\mathrm{HDO}$ & 411 \\
\hline $408-\mathrm{CO}$ & 380 & $411-\mathrm{CO}$ & 383 \\
\hline $380-\mathrm{H}_{3} \mathrm{C}-\mathrm{N}=\mathrm{CH}_{2}$ & 337 & $383-\mathrm{H}_{3} \mathrm{C}-\mathrm{N}=\mathrm{CH}_{2}$ & 340 \\
\hline $408-\mathrm{H}_{3} \mathrm{C}-\mathrm{N}=\mathrm{CH}_{2}$ & 365 & $411-\mathrm{H}_{3} \mathrm{C}-\mathrm{N}=\mathrm{CH}_{2}$ & 368 \\
\hline $365-\mathrm{CH}_{3}$ & 350 & $368-\mathrm{CH}_{3}$ & 353 \\
\hline $350-\mathrm{CO}$ & 322 & $353-\mathrm{CO}$ & 325 \\
\hline $322-\mathrm{CO}$ & 294 & $325-\mathrm{CO}$ & 297 \\
\hline $426-\left(\mathrm{H}_{3} \mathrm{C}\right)_{2}-\mathrm{NH}$ & 381 & $430-\left(\mathrm{H}_{3} \mathrm{C}\right)_{2}-\mathrm{ND}$ & 384 \\
\hline $381-\mathrm{CO}$ & 353 & $384-\mathrm{CO}$ & 356 \\
\hline $353-\mathrm{H}_{2} \mathrm{O}$ & 335 & $356-\mathrm{HDO}$ & 337 \\
\hline $381-\mathrm{H}_{2} \mathrm{O}$ & 363 & $384-\mathrm{HDO}$ & 365 \\
\hline $363-\mathrm{CO}$ & 335 & $365-\mathrm{CO}$ & 337 \\
\hline $335-\mathrm{CO}$ & 307 & $337-\mathrm{CO}$ & 309 \\
\hline $426-226+H$ & 201 & $430-229+D$ & 203 \\
\hline $461-\mathrm{NH}_{3}-218$ & 226 & $470-N_{3}-221$ & 229 \\
\hline $226-\mathrm{CO}^{\circ}$ & 198 & $229-\mathrm{CO}$ & 201 \\
\hline $226-\mathrm{H}_{2} \mathrm{O}$ & 208 & $229-\mathrm{D}_{2} \mathrm{O}$ & 209 \\
\hline $208-\mathrm{CO}$ & 180 & $209-\mathrm{CO}$ & 181 \\
\hline $180-\mathrm{CO}$ & 152 & $181-\mathrm{CO}$ & 153 \\
\hline $226-72$ & 154 & $229-74$ & 155 \\
\hline $154-\mathrm{CO}$ & 126 & $155-\mathrm{CO}$ & 127 \\
\hline $126-\mathrm{CO}$ & 98 & $127-\mathrm{CO}$ & 99 \\
\hline $126-\mathrm{C}_{3} \mathrm{O}_{2}$ & 58 & $127-\mathrm{C}_{3} \mathrm{O}_{2}$ & 59 \\
\hline
\end{tabular}

Chlorotetracycline $\left(\mathrm{MW}=478,[\mathrm{M}+\mathrm{H}]^{+}=479,[\mathrm{M}(\mathrm{d} 7)+\mathrm{D}]^{+}=487\right)$ $479-\mathrm{H}_{2} \mathrm{O} \quad 461487-\mathrm{D}_{2} \mathrm{O}$ $461-\mathrm{NH}_{3} \quad 444 \quad 467-\mathrm{ND}_{3} \quad 447$ $444-\mathrm{H}_{2} \mathrm{O} \quad 426 \quad 447-\mathrm{HDO} \quad 428$

$426-\mathrm{CO}$

$426-\mathrm{H}_{3} \mathrm{C}-\mathrm{N}=\mathrm{CH}_{2}$ $383-\mathrm{CO}$

$426-\mathrm{CH}_{3}$

$444-\mathrm{CO}$

$444-\left(\mathrm{H}_{3} \mathrm{C}\right)_{2}-\mathrm{NH}$

$399-\mathrm{CO}$

$399-\mathrm{H}_{2} \mathrm{O}$

$479-\mathrm{NH}_{3}-308$

$154-\mathrm{CO}$

$126-\mathrm{CO}$

$126-\mathrm{C}_{3} \mathrm{O}_{2}$

minocycline $\left(\mathrm{MW}=457,[\mathrm{M}+\mathrm{H}]^{+}=458,[\mathrm{M}(\mathrm{d} 6)+\mathrm{D}]^{+}=465\right)$

$458-\mathrm{NH}_{3} \quad 441 \quad 465-\mathrm{ND}_{3}$

445

(continued)
Table 1. (continued)

\begin{tabular}{|c|c|c|c|}
\hline Product Ion & $m / z$ & $\begin{array}{l}\text { Deuterated } \\
\text { product ion }\end{array}$ & $\begin{array}{c}\text { Deuterated } \\
\mathrm{m} / \mathrm{z}\end{array}$ \\
\hline $441-\mathrm{H}_{2} \mathrm{O}$ & 423 & $445-\mathrm{D}_{2} \mathrm{O}$ & 425 \\
\hline $423-\mathrm{CO}$ & 395 & 425- CO & 397 \\
\hline $395-\mathrm{H}_{3} \mathrm{C}-\mathrm{N}=\mathrm{CH}_{2}$ & 352 & $397-\mathrm{H}_{3} \mathrm{C}-\mathrm{N}=\mathrm{CH}_{2}$ & 354 \\
\hline $395-\mathrm{CO}$ & 367 & $397-\mathrm{CO}$ & 369 \\
\hline $395-\mathrm{CH}_{3}$ & 380 & $397-\mathrm{CH}_{3}$ & 382 \\
\hline $380-\mathrm{CH}_{3}$ & 365 & $382-\mathrm{CH}_{3}$ & 367 \\
\hline $423-\mathrm{CH}_{3}$ & 408 & $425-\mathrm{CH}_{3}$ & 410 \\
\hline $408-\mathrm{CO}$ & 380 & $410-\mathrm{CO}$ & 382 \\
\hline $408-\mathrm{H}_{3} \mathrm{C}-\mathrm{N}=\mathrm{CH}_{2}$ & 365 & $410-\mathrm{H}_{3} \mathrm{C}-\mathrm{N}=\mathrm{CH}_{2}$ & 367 \\
\hline $365-\mathrm{CO}$ & 337 & $367-\mathrm{CO}$ & 339 \\
\hline $337-\mathrm{CO}$ & 309 & $339-\mathrm{CO}$ & 311 \\
\hline $337-\mathrm{CH}_{3}$ & 322 & $339-\mathrm{CH}_{3}$ & 324 \\
\hline $337-\mathrm{C}_{4} \mathrm{H}_{6}$ & 283 & $339-\mathrm{C}_{4} \mathrm{H}_{6}$ & 285 \\
\hline $458-\mathrm{NH}_{3}-287$ & 154 & $465-N_{3}-290$ & 155 \\
\hline $154-\mathrm{CO}$ & 126 & $155-\mathrm{CO}$ & 127 \\
\hline $126-\mathrm{CO}$ & 98 & $127-\mathrm{CO}$ & 99 \\
\hline $\begin{array}{l}126-\mathrm{C}_{3} \mathrm{O}_{2} \\
\text { methacycline }(\mathrm{MW}=\end{array}$ & $\begin{array}{r}58 \\
2 .[M\end{array}$ & $\begin{array}{l}127-\mathrm{C}_{3} \mathrm{O}_{2} \\
\mathrm{H}]^{+}=443 \cdot[\mathrm{M}(\mathrm{d} 7)+\end{array}$ & $\begin{aligned} & 59 \\
\mathrm{Dl}^{+}= & 451)\end{aligned}$ \\
\hline $443-\mathrm{NH}_{3}$ & 426 & $451-N_{3}$ & 431 \\
\hline $426-\mathrm{CO}$ & 398 & $431-\mathrm{CO}$ & 403 \\
\hline $426-\left(\mathrm{H}_{3} \mathrm{C}\right)_{2}-\mathrm{NH}$ & 381 & $431-\left(\mathrm{H}_{3} \mathrm{C}\right)_{2}-\mathrm{ND}$ & 385 \\
\hline $381-\mathrm{CO}$ & 353 & $385-\mathrm{CO}$ & 357 \\
\hline $353-\mathrm{CO}$ & 325 & $357-\mathrm{CO}$ & 329 \\
\hline $381-\mathrm{H}_{2} \mathrm{O}$ & 363 & $385-\mathrm{HDO}$ & 366 \\
\hline $363-\mathrm{CO}$ & 335 & $366-\mathrm{CO}$ & 338 \\
\hline $335-\mathrm{CO}$ & 301 & $338-\mathrm{CO}$ & 310 \\
\hline $307-\mathrm{CO}$ & 279 & $310-\mathrm{CO}$ & 282 \\
\hline $335-\mathrm{H}_{2} \mathrm{O}$ & 317 & $338-\mathrm{HDO}$ & 319 \\
\hline $426-\mathrm{H}_{2} \mathrm{O}$ & 408 & $431-\mathrm{HDO}$ & 412 \\
\hline $408-\mathrm{H}_{2} \mathrm{O}$ & 390 & $412-\mathrm{HDO}$ & 393 \\
\hline $408-\mathrm{H}_{3} \mathrm{C}-\mathrm{N}=\mathrm{CH}_{2}$ & 365 & $412-\mathrm{H}_{3} \mathrm{C}-\mathrm{N}=\mathrm{CH}_{2}$ & 369 \\
\hline $408-\mathrm{CO}$ & 380 & $412-\mathrm{CO}$ & 384 \\
\hline $380-\mathrm{H}_{3} \mathrm{C}-\mathrm{N}=\mathrm{CH}_{2}$ & 337 & $384-\mathrm{H}_{3} \mathrm{C}-\mathrm{N}=\mathrm{CH}_{2}$ & 341 \\
\hline $426-226+H$ & 201 & $431-229+D$ & 204 \\
\hline $426-200$ & 226 & $431-202$ & 229 \\
\hline $226-\mathrm{CO}$ & 198 & $229-\mathrm{CO}$ & 201 \\
\hline $226-\mathrm{H}_{2} \mathrm{O}$ & 208 & $229-\mathrm{D}_{2} \mathrm{O}$ & 209 \\
\hline $208-\mathrm{CO}$ & 180 & $209-\mathrm{CO}$ & 181 \\
\hline $180-\mathrm{CO}$ & 152 & $181-\mathrm{CO}$ & 153 \\
\hline $226-72$ & 154 & $229-74$ & 155 \\
\hline $154-\mathrm{CO}$ & 126 & $155-\mathrm{CO}$ & 127 \\
\hline $126-\mathrm{CO}$ & 98 & $127-\mathrm{CO}$ & 99 \\
\hline $126-\mathrm{C}_{3} \mathrm{O}_{2}$ & 58 & $127-\mathrm{C}_{3} \mathrm{O}_{2}$ & 59 \\
\hline
\end{tabular}

should be slightly larger than $\mathrm{GB}\left\{\mathrm{s}-\mathrm{C}_{4} \mathrm{H}_{9} \mathrm{~N}\left(\mathrm{CH}_{3}\right)_{2}\right\}=$ $945 \mathrm{~kJ} / \mathrm{mol}$. The basicity of the amide group at C-2 should be similar to $\left.\mathrm{GB}_{2} \mathrm{C}_{2} \mathrm{H}_{5} \mathrm{CONH}_{2}\right\}=845 \mathrm{~kJ} / \mathrm{mol}$ or $\mathrm{GB}\left\{\mathrm{CH}_{2}=\mathrm{CHCONH}_{2}\right\}=840 \mathrm{~kJ} / \mathrm{mol}$. The basicities of the hydroxyl groups should be similar to and perhaps slightly larger than the basicities of s- $\mathrm{C}_{4} \mathrm{H}_{9} \mathrm{OH}$ at 785 $\mathrm{kJ} / \mathrm{mol}$ and $\mathrm{t}-\mathrm{C}_{4} \mathrm{H}_{9} \mathrm{OH}$ at $772 \mathrm{~kJ} / \mathrm{mol}$. The basicity of the phenolic $\mathrm{OH}$ at $\mathrm{C}-10$ should be slightly larger than $\mathrm{GB}\{$ phenol $\}=786 \mathrm{~kJ} / \mathrm{mol}$. The basicities of the carbonyl groups at C-1 and C-11 should be similar to GB\{3-hexen2 -one $\}=834 \mathrm{~kJ} / \mathrm{mol}$. All of these data are at $298 \mathrm{~K}$.

The ratio of equilibrium concentrations of species protonated at two sites should be given approximately by $\exp (-\Delta \mathrm{GB} / \mathrm{RT})$, where $\Delta \mathrm{GB}$ is the difference in gas phase basicities of the two sites, $\mathrm{R}$ is the gas constant, and $\mathrm{T}$ is the temperature. Then the ratio of hydroxyl- 

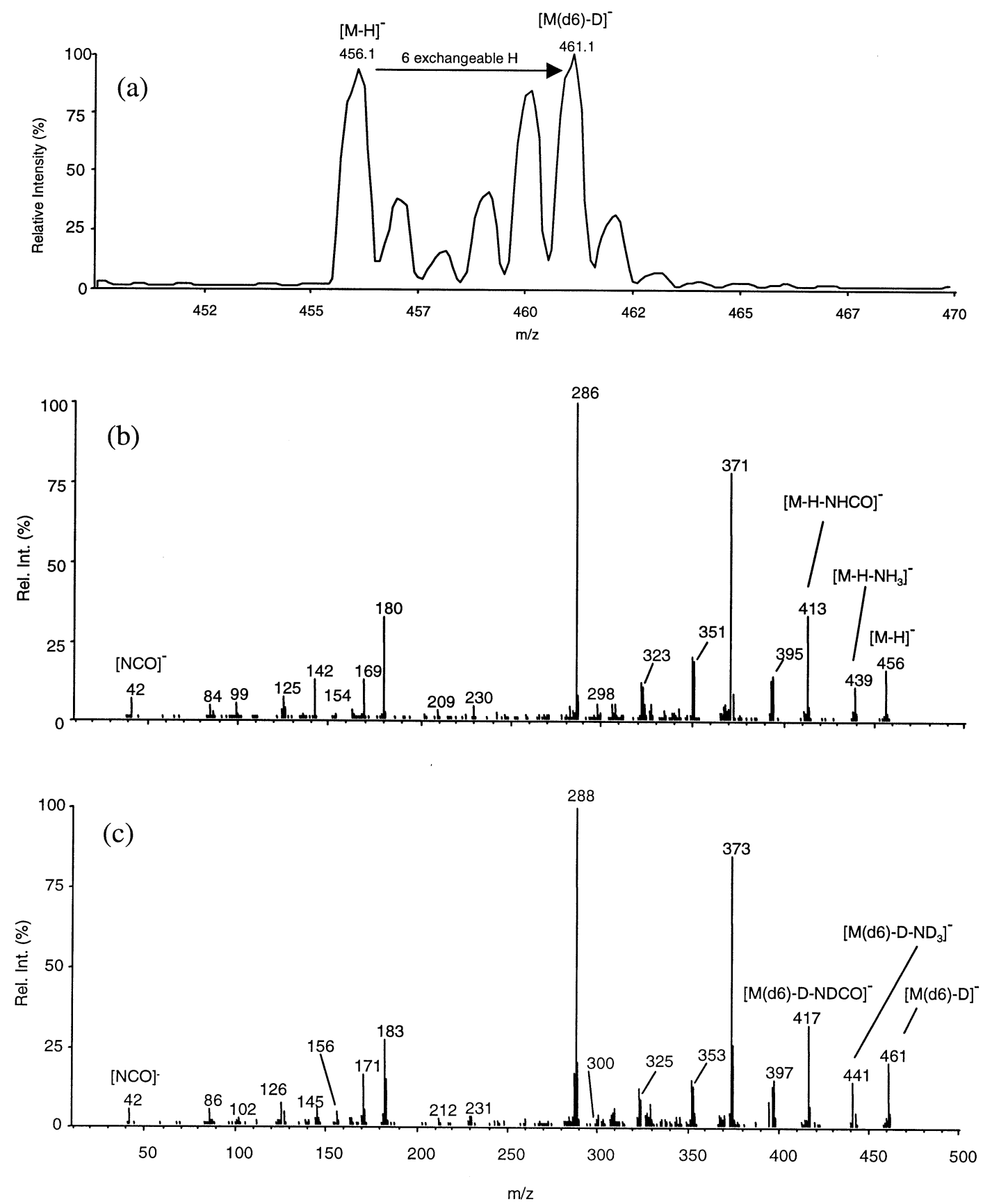

Figure 8. Negative ion ESI mass spectra of minocycline (MW = 457): (a) total ion current (TIC) showing both $[\mathrm{M}-\mathrm{H}]^{-}$and $[\mathrm{M}(\mathrm{d} 6)-\mathrm{D}]^{-}$in a single experiment (b) CID product ion spectrum of $[\mathrm{M}$ $-\mathrm{H}^{-}$at $\mathrm{m} / \mathrm{z} 456$ at a collision energy of $-20 \mathrm{eV}$ (c) CID product ion spectrum of the fully exchanged $[\mathrm{M}(\mathrm{d} 6)-\mathrm{D}]^{-}$at $m / z 461$ at a collision energy of $-20 \mathrm{eV}$. Deuteration was achieved by nebulizer $\mathrm{ND}_{3}$ gas phase H/D exchange on a Sciex API-III ${ }^{+}$triple quadrupole mass spectrometer.

protonated to dimethylamino-protonated species is vanishingly small: Approximately $\exp \left(-177^{*} 10^{3} / \mathrm{RT}\right)=$ $10^{-31}$ at $298 \mathrm{~K}$. Although these numbers are not accurate, any reasonable estimate of the basicities of the sites in the tetracyclines indicates negligible equilibrium concentrations of species protonated at C-6.

The basicity of the amide site in the tetracyclines should be increased significantly by intramolecular solvation of $-\mathrm{NH}_{3}^{+}$with the hydroxyl group at C-3. The free energy of solvation of $\mathrm{NH}_{4}^{+}$with $\mathrm{H}_{2} \mathrm{O}$ is $\sim-50$ $\mathrm{kJ} / \mathrm{mol}$ and a similar value of $\sim 50 \mathrm{~kJ} / \mathrm{mol}$ is reported for the free energy of solvation of $\mathrm{CH}_{3} \mathrm{NH}_{3}^{+}$with $\mathrm{CH}_{3} \mathrm{OH}$ [47]. Including the solvation energy, one would estimate that the GB(dimethylamino group) -GB (amide) $\sim 50 \mathrm{~kJ} / \mathrm{mol}$. Consequently, one would estimate that the ratio of amide-protonated to dimethylaminoprotonated species would be $\sim 10^{-9}$ at $298 \mathrm{~K}$. Although this value is much larger than the ratio of hydroxyl- 
Table 2. Gas phase acidities of anions

\begin{tabular}{|c|c|c|c|}
\hline Anion & Compound name & $\Delta \mathrm{H}^{\circ}, \mathrm{kJ} / \mathrm{mol}$ & $\Delta \mathrm{G}^{\circ}, \mathrm{kJ} / \mathrm{mol}$ \\
\hline & Phenol & $1461-1471$ & $1432-1437$ \\
\hline & o-methyl phenol & $1462-1465$ & $1431-1434$ \\
\hline & p-dimethylaminophenol & $1470 \pm 9$ & $1441 \pm 8$ \\
\hline & 3-methylpentanol & $1556 \pm 12$ & $1528 \pm 11$ \\
\hline & cyclohexanone & $1543 \pm 18$ & $1511 \pm 17$ \\
\hline & acetaldehyde & $1533 \pm 12$ & $1505 \pm 8$ \\
\hline $\mathrm{H}_{2} \mathrm{C}=\mathrm{CH}-\stackrel{\ominus}{\ominus}$ & acetamide & $1515 \pm 9$ & $1485 \pm 8$ \\
\hline
\end{tabular}

Data from Ref. 45.

protonated to dimethylamino-protonated species, it is still a very small number and one would estimate that the $[\mathrm{M}+\mathrm{H}]^{+}$ions would be almost exclusively dimethylamino-protonated.

One may also estimate the thermochemistry for the cleavage reactions from data for simple model compounds. Protonation at the dimethylamino group followed by loss of dimethylamine would be similar to the decomposition of protonated dimethylalkylammonium ions. Data are available to estimate the heat of the following reaction, $\mathrm{s}-\mathrm{C}_{4} \mathrm{H}_{9} \mathrm{NH}\left(\mathrm{CH}_{3}\right)_{2}^{+} \rightarrow \mathrm{s}^{-} \mathrm{C}_{4} \mathrm{H}_{9}^{+}+$ $\mathrm{NH}\left(\mathrm{CH}_{3}\right)_{2}$, for which $\Delta \mathrm{H}^{\mathrm{o}}(298) \sim 330 \mathrm{~kJ} / \mathrm{mol}$. Loss of $\mathrm{NH}_{3}$ from the amide-protonated species would be similar to the decomposition of protonated propanamide, $\mathrm{C}_{2} \mathrm{H}_{5} \mathrm{CONH}_{3}^{+} \rightarrow \mathrm{C}_{2} \mathrm{H}_{5} \mathrm{CO}^{+}+\mathrm{NH}_{3}$, for which $\Delta \mathrm{H}^{\mathrm{o}}(298)$ $\sim 150 \mathrm{~kJ} / \mathrm{mol}$. Loss of water from the species protonated on the hydroxyl group at C-6 would be similar to the decomposition of protonated t-butyl alcohol, $\mathrm{t}-\mathrm{C}_{4} \mathrm{H}_{9} \mathrm{OH}_{2}^{+} \rightarrow \mathrm{t}-\mathrm{C}_{4} \mathrm{H}_{9}^{+}+\mathrm{H}_{2} \mathrm{O}$, for which $\Delta \mathrm{H}^{\mathrm{o}}(298) \sim 55$ $\mathrm{kJ} / \mathrm{mol}$. For these competing cleavage reactions, one may assume that activation energies for the decompositions are similar to the heats of reaction. Consequently, the loss of water would be expected to be the fastest decomposition process, by a very large margin. Loss of ammonia from the protonated amide would be the second most likely cleavage reaction.

In these experiments, there are multiple collisions before the $[\mathrm{M}+\mathrm{H}]^{+}$ions are activated sufficiently to decompose. Consequently, we may assume that a proton is transferred to the C-6 hydroxyl group in the collisional activation process and that this ion then rapidly decomposes with the loss of water. Similar reasoning would explain the loss of ammonia.

The low energy CID spectra do not give sufficient fragmentation for characterization of the tetracyclines. However, as noted in Figure 3a, increasing the collision energy greatly increases the extent of fragmentation. Figure 5 shows CID spectra of the $[\mathrm{M}+\mathrm{H}]^{+}$ions from oxytetracycline and the $[\mathrm{M}(\mathrm{D} 8)+\mathrm{D}]^{+}$analog of the species produced by gas phase exchange using $\mathrm{ND}_{3}$. These spectra were obtained with Ar as the collision gas at collision energy of $25 \mathrm{eV}$, with corresponds to $\sim 2 \mathrm{eV}$ in the center of mass system.

Figure 5a shows spectra in the molecular weight region from two sets of experiments on a single loop injection of oxytetracycline using the API Sciex III ${ }^{\text {plus }}$ mass spectrometer. The protonated species and the 25 $\mathrm{eV} \mathrm{CID} \mathrm{spectrum} \mathrm{of}[\mathrm{M}+\mathrm{H}]^{+}$at $m / z 461$ (Figure $5 \mathrm{~b}$ ) are obtained using $\mathrm{N}_{2}$ as the nebulizer gas. Then $\mathrm{ND}_{3}$ is introduced as the nebulizer gas for H/D exchange. Although partially exchanged ions are observed, the shift from $m / z 461$ to $m / z 470$ (Figure 5a) shows eight exchangeable hydrogens in the molecule. The $25 \mathrm{eV}$ spectrum of the $\left[\mathrm{M}\left(\mathrm{D}_{8}\right)+\mathrm{D}\right]^{+}$ions at $m / z 470$ is also obtained during this injection (Figure $5 \mathrm{c}$ ). The correct number of exchangeable hydrogens was detected from similar experiments with all five of these tetracyclines.

A comparison of Figures $5 b$ and $c$ provides some information about the product ions. The ions at $m / z 443$ or at 444 in Figure $5 \mathrm{~b}$ correspond to loss of $\mathrm{H}_{2} \mathrm{O}$ or $\mathrm{NH}_{3}$ (or $\mathrm{OH}$ ) from $[\mathrm{M}+\mathrm{H}]^{+}$at $m / z$ 461. A single peak is observed at $m / z 450$, corresponding to the loss of $\mathrm{D}_{2} \mathrm{O}$ 
Table 3. Principal dissociation products of deprotonated tetracyclines

\begin{tabular}{|c|c|c|c|}
\hline Product Ion & $m / z$ & Deuterated product ion & Deuterated $\mathrm{m} / \mathrm{z}$ \\
\hline \multicolumn{4}{|c|}{ tetracycline $\left(\mathrm{MW}=444,[\mathrm{M}-\mathrm{H}]^{-}=443,[\mathrm{M}(\mathrm{d} 7)-\mathrm{D}]^{-}=449\right)$} \\
\hline $443-\mathrm{NHCO}$ & 400 & $449-$ NDCO & 405 \\
\hline $443-\mathrm{NH}_{3}$ & 426 & $449-N_{3}$ & 429 \\
\hline $426-\mathrm{H}_{2} \mathrm{O}$ & 408 & $429-\mathrm{D}_{2} \mathrm{O}$ & 409 \\
\hline $426-\mathrm{CO}$ & 398 & $429-\mathrm{CO}$ & 401 \\
\hline $426-. \mathrm{N}\left(\mathrm{CH}_{3}\right)_{2}$ & 382 & $429-\mathrm{N}\left(\mathrm{CH}_{3}\right)_{2}$ & 385 \\
\hline $382-\mathrm{CO}$ & 354 & $385-\mathrm{CO}$ & 357 \\
\hline $426-\mathrm{C}_{3} \mathrm{O}_{2}$ & 358 & $429-\mathrm{C}_{3} \mathrm{O}_{2}$ & 361 \\
\hline $358-\mathrm{O}=\mathrm{C}=\mathrm{CH}-\mathrm{N}\left(\mathrm{CH}_{3}\right)_{2}$ & 273 & $361-\mathrm{O}=\mathrm{C}=\mathrm{CH}-\mathrm{N}\left(\mathrm{CH}_{3}\right)_{2}$ & 276 \\
\hline \multicolumn{4}{|c|}{ oxytetracycline $\left(\mathrm{MW}=460,[\mathrm{M}-\mathrm{H}]^{-}=459,[\mathrm{M}(\mathrm{d} 8)-\mathrm{D}]^{-}=466\right)$} \\
\hline $459-\mathrm{NHCO}$ & 416 & $466-\mathrm{NDCO}$ & 422 \\
\hline $459-\mathrm{NH}_{3}$ & 442 & $466-\mathrm{ND}_{3}$ & 446 \\
\hline $442-\mathrm{H}_{2} \mathrm{O}$ & 424 & $446-\mathrm{D}_{2} \mathrm{O}$ & 426 \\
\hline $442-\mathrm{CO}$ & 414 & $446-\mathrm{CO}$ & 418 \\
\hline $442-. \mathrm{N}\left(\mathrm{CH}_{3}\right)_{2}$ & 398 & $446-. \mathrm{N}\left(\mathrm{CH}_{3}\right)_{2}$ & 402 \\
\hline $398-\mathrm{CO}$ & 370 & $402-\mathrm{CO}$ & 374 \\
\hline $442-\mathrm{C}_{3} \mathrm{O}_{2}$ & 374 & $446-\mathrm{C}_{3} \mathrm{O}_{2}$ & 378 \\
\hline $374-\mathrm{O}=\mathrm{C}=\mathrm{CH}-\mathrm{N}\left(\mathrm{CH}_{3}\right)_{2}$ & 289 & $378-\mathrm{O}=\mathrm{C}=\mathrm{CH}-\mathrm{N}\left(\mathrm{CH}_{3}\right)_{2}$ & 293 \\
\hline \multicolumn{4}{|c|}{ chlorotetracycline $\left(\mathrm{MW}=478,[\mathrm{M}-\mathrm{H}]^{-}=477,[\mathrm{M}(\mathrm{d} 7)-\mathrm{D}]^{-}=483\right)$} \\
\hline $477-\mathrm{NHCO}$ & 434 & $483-\mathrm{NDCO}$ & 439 \\
\hline $477-\mathrm{NH}_{3}$ & 460 & $483-N_{3}$ & 463 \\
\hline $460-\mathrm{H}_{2} \mathrm{O}$ & 442 & $463-\mathrm{HDO}$ & 444 \\
\hline $460-\mathrm{CO}$ & 432 & $463-\mathrm{CO}$ & 435 \\
\hline $460-. \mathrm{N}\left(\mathrm{CH}_{3}\right)_{2}$ & 416 & $463-. \mathrm{N}\left(\mathrm{CH}_{3}\right)_{2}$ & 419 \\
\hline $416-\mathrm{CO}$ & 388 & $419-\mathrm{CO}$ & 391 \\
\hline $460-\mathrm{C}_{3} \mathrm{O}_{2}$ & 392 & $463-\mathrm{C}_{3} \mathrm{O}_{2}$ & 395 \\
\hline $392-\mathrm{O}=\mathrm{C}=\mathrm{CH}-\mathrm{N}\left(\mathrm{CH}_{3}\right)_{2}$ & 307 & $395-\mathrm{O}=\mathrm{C}=\mathrm{CH}-\mathrm{N}\left(\mathrm{CH}_{3}\right)_{2}$ & 310 \\
\hline \multicolumn{4}{|c|}{ minocycline $\left(\mathrm{MW}=457,[\mathrm{M}-\mathrm{H}]^{-}=456,[\mathrm{M}(\mathrm{d} 6)-\mathrm{D}]^{-}=461\right)$} \\
\hline $456-\mathrm{NHCO}$ & 413 & $461-\mathrm{NDCO}$ & 417 \\
\hline $456-\mathrm{NH}_{3}$ & 439 & $461-N_{3}$ & 441 \\
\hline $439-\mathrm{H}_{2} \mathrm{O}$ & 421 & $441-\mathrm{HDO}$ & 422 \\
\hline $439-\mathrm{CO}$ & 411 & $441-\mathrm{CO}$ & 413 \\
\hline $439-. \mathrm{N}\left(\mathrm{CH}_{3}\right)_{2}$ & 395 & $441-. \mathrm{N}\left(\mathrm{CH}_{3}\right)_{2}$ & 397 \\
\hline $395-\mathrm{CO}$ & 367 & $397-\mathrm{CO}$ & 369 \\
\hline $439-\mathrm{CO}_{2}$ & 371 & $441-\mathrm{C}_{3} \mathrm{O}_{2}$ & 373 \\
\hline $371-\mathrm{O}=\mathrm{C}=\mathrm{CH}-\mathrm{N}\left(\mathrm{CH}_{3}\right)_{2}$ & 286 & $373-\mathrm{O}=\mathrm{C}=\mathrm{CH}-\mathrm{N}\left(\mathrm{CH}_{3}\right)_{2}$ & 288 \\
\hline \multicolumn{4}{|c|}{ methacycline $\left(\mathrm{MW}=442,[\mathrm{M}-\mathrm{H}]^{-}=443,[\mathrm{M}(\mathrm{d} 7)-\mathrm{D}]^{-}=447\right)$} \\
\hline $441-\mathrm{NHCO}$ & 398 & $447-\mathrm{NDCO}$ & 403 \\
\hline $441-\mathrm{NH}_{3}$ & 424 & $447-N_{3}$ & 427 \\
\hline $424-\mathrm{H}_{2} \mathrm{O}$ & 406 & 427 - HDO & 408 \\
\hline $424-\mathrm{CO}$ & 396 & $427-\mathrm{CO}$ & 399 \\
\hline $396-\mathrm{CO}$ & 368 & $399-\mathrm{CO}$ & 371 \\
\hline $424-\mathrm{N}\left(\mathrm{CH}_{3}\right)_{2}$ & 380 & $427-\mathrm{N}\left(\mathrm{CH}_{3}\right)_{2}$ & 383 \\
\hline $380-\mathrm{CO}$ & 352 & $383-\mathrm{CO}$ & 355 \\
\hline $352-\mathrm{H}_{2} \mathrm{O}$ & 334 & $355-\mathrm{HDO}$ & 336 \\
\hline $424-\mathrm{C}_{3} \mathrm{O}_{2}$ & 356 & $427-\mathrm{C}_{3} \mathrm{O}_{2}$ & 359 \\
\hline $356-\mathrm{O}=\mathrm{C}=\mathrm{CH}-\mathrm{N}\left(\mathrm{CH}_{3}\right)_{2}$ & 271 & $359-\mathrm{O}=\mathrm{C}=\mathrm{CH}-\mathrm{N}\left(\mathrm{CH}_{3}\right)_{2}$ & 274 \\
\hline
\end{tabular}

and $\mathrm{ND}_{3}$ (not OD) from $\left[\mathrm{M}\left(\mathrm{D}_{8}\right)+\mathrm{D}\right]^{+}$at $m / z$ 470. The most abundant fragment ion, $\left[\mathrm{M}+\mathrm{H}-\mathrm{H}_{2} \mathrm{O}-\mathrm{NH}_{3}\right]^{+}$at $m / z 426$ in Figure $5 b$, is predominantly $\left[\mathrm{M}\left(\mathrm{D}_{8}\right)+\mathrm{D}-\right.$ $\left.\mathrm{D}_{2} \mathrm{O}-\mathrm{ND}_{3}\right]^{+}$at $\mathrm{m} / z 430$ from the fully exchanged species. The fragment ions from $\mathrm{m} / \mathrm{z} 226$ to 408 in Figure $5 \mathrm{~b}$ contain three exchangeable hydrogens because the $\mathrm{m} / \mathrm{z}$ values are increased by three in Figure $5 \mathrm{c}$. There is a small amount of scrambling of exchangeable and carbon bound hydrogens in the major decomposition processes.

Additional experiments were done to analyze the decomposition processes using multi-stage $\mathrm{CID}, \mathrm{MS}^{N}$, with an ion trap on $[\mathrm{M}+\mathrm{H}]^{+}$from oxytetracycline and
$\left[\mathrm{M}\left(\mathrm{D}_{8}\right)+\mathrm{D}\right]^{+}$from oxytetracycline that had undergone essentially complete $H / D$ exchange in the liquid phase: $I_{i}(461) / I_{i}(470)$ in the ESI spectrum. As mentioned earlier in this report, the CID of $\left[\mathrm{M}\left(\mathrm{D}_{8}\right)+\mathrm{D}\right]^{+}$showed water loss as essentially the only product and $\sim 90 \%$ of this loss was $\mathrm{D}_{2} \mathrm{O}$ (the other $\sim 10 \%$ loss was $\mathrm{HDO}$ at $\mathrm{m} / \mathrm{z}$ 451). The CID spectrum of $\left[\mathrm{M}+\mathrm{H}-\mathrm{H}_{2} \mathrm{O}\right]^{+}$at $m / z 443$ contains one major peak at $m / z 426$ and the CID spectrum of the analogous deuterated species, $\left[\mathrm{M}\left(\mathrm{D}_{8}\right)+\right.$ $\left.\mathrm{D}-\mathrm{D}_{2} \mathrm{O}\right]^{+}$at $m / z 450$, shows that this peak is $\sim 90 \%$ loss of $\mathrm{ND}_{3}$ at $m / z 430$ and $\sim 10 \%$ loss of HDO at $m / z 431$. Scheme 1 shows a proposed mechanism for the loss of $\mathrm{H}_{2} \mathrm{O}\left(\mathrm{D}_{2} \mathrm{O}\right)$ followed by the loss of $\left(\mathrm{NH}_{3}\right) \mathrm{ND}_{3}$. 
Figure 6 shows the more complex CID decomposition pattern for the non-deuterated/deuterated fragment ions at $m / z 426$ and 430 . The $426^{+} \rightarrow 408^{+}+$ $\mathrm{H}_{2} \mathrm{O}$ decomposition for the non-deuterated species is predominantly shifted to $430^{+} \rightarrow 411^{+}+$HDO or to $430^{+} \rightarrow 410^{+}+\mathrm{D}_{2} \mathrm{O}$ (minor pathway) for the deuterated species. The $426^{+} \rightarrow 381^{+}+45$ decomposition for the non-deuterated species is shifted to $430^{+} \rightarrow$ $384^{+}+46$ for the deuterated species. CID experiments on the ions at $m / z 408$ (411, deuterated, Figure 7) show product ions at $m / z 337(339,340)$, at $m / z 365$ (368), and minor ions at $m / z 380(382,383)$ but not at $\mathrm{m} / \mathrm{z} 381$ (384). Consequently, the ions at $\mathrm{m} / \mathrm{z} 426$ (430) decompose by competing processes to give ions at $m / z 381$ (384), at $m / z 408$ (411) and at $m / z 408$ (410). Schemes 2 and 3 show proposed mechanisms for the decomposition of the ions at $m / z 426$ (430) to give rise to ion at $m / z 381$ (384) and ions at $m / z 408$ (411) and at $m / z 408$ (410), respectively. The other high mass fragment ions in those competitive processes can be explained from losses of $\mathrm{H}_{2} \mathrm{O}, \mathrm{CO}$, and $\mathrm{CH}_{3} \mathrm{NCH}_{2}$.

The ions at $m / z 226$ contain three exchangeable hydrogens, as indicated by the shift to $m / z 229$ in Figure 6 for the deuterated species. The CID spectra of ions at $m / z 226$ (229), data not shown, show competing losses of $\mathrm{CO}$ and $\mathrm{H}_{2} \mathrm{O}\left(\mathrm{D}_{2} \mathrm{O}\right)$ to form product ions at $m / z 198$ (201) and at $m / z 208$ (209). The ions at $m / z 208$ (209) decomposed by loss of CO. Reasonable mechanisms for the formation of these ions and subsequent decomposition reactions can be proposed, but not strongly defended.

Table 1 shows the principal positive ion dissociation products for these tetracyclines for the undeuterated and deuterated species. These assignments were made from $\mathrm{MS}^{N}$ spectra on un-deuterated and deuterated ions. The low mass fragment ions at $m / z 58$ (59), 98 (99), 126 (127), and 154 (155) all contain one exchangeable hydrogen and probably originate from the A-ring of the tetracyclines because they are observed for all five of these compounds. The major decomposition paths are similar for all of these compounds except that minocycline and methacycline (without a tertiary $\mathrm{OH}$ at C-6) do not lose water from $[\mathrm{M}+\mathrm{H}]^{+}$.

\section{Negative Ions}

The tetracyclines can be analyzed as negative ions as well as positive ions [40]. Figure 8 shows CID spectra for the $[\mathrm{M}-\mathrm{H}]^{-}$ions from minocycline and the $\left[\mathrm{M}\left(\mathrm{D}_{6}\right)-\mathrm{D}\right]^{-}$analog of the species produced by gas phase exchange using $\mathrm{ND}_{3}$. Figure 8a shows spectrum obtained in the molecular weight region from two sets of experiments during sample infusion of minocycline using the API Sciex III ${ }^{\text {plus }}$ mass spectrometer. The de-protonated species and the $20 \mathrm{eV}$ CID spectrum of $[\mathrm{M}-\mathrm{H}]^{-}$at $m / z 456$ (Figure $8 b$ ) are obtained using $\mathrm{N}_{2}$ as the nebulizer gas. Then $\mathrm{ND}_{3}$ is introduced as the nebulizer gas for H/D exchange. Although partially exchanged ions are observed, the shift from $m / z 456$ to $m / z 461$ (Figure 8a) shows six exchangeable hydrogens in the molecule (the positive ion spectra showed the expected increase of seven for the exchanged species). The correct number of exchangeable hydrogens was detected in similar negative ion experiments with all five of the tetracyclines. The $20 \mathrm{eV}$ spectrum of the $\left[\mathrm{M}\left(\mathrm{D}_{6}\right)-\mathrm{D}\right]^{-}$ions at $\mathrm{m} / \mathrm{z}$ 461 is also obtained after the introduction of $\mathrm{ND}_{3}$ as the nebulizer gas (Figure 8c).

A comparison of Figures $8 \mathrm{~b}$ and $\mathrm{c}$ provides some information about the product ions. The ions at $\mathrm{m} / \mathrm{z}$ 439 in Figure $8 \mathrm{~b}$ correspond to loss of $\mathrm{NH}_{3}$ or $\mathrm{OH}$ from $[\mathrm{M}-\mathrm{H}]^{-}$at $m / z 456$. The analogous peak for the deuterated compound is observed in Figure $8 \mathrm{c}$ at $\mathrm{m} / \mathrm{z}$ 441 , corresponding to the loss of $\mathrm{ND}_{3}$ (not OD) from $\left[\mathrm{M}\left(\mathrm{D}_{6}\right)-\mathrm{D}\right]^{-}$at $m / z$ 461. The other high mass fragment ions $(m / z 286-395)$ are shifted by two mass units from Figure $8 \mathrm{~b}$ to Figure $8 \mathrm{c}$ and contain two exchangeable hydrogens. The fragment ion at $m / z 180$ in Figure $8 \mathrm{~b}$ cannot come from decomposition of any of these ions because it contains three exchangeable hydrogens (shifted to $m / z 183$ in Figure 8c). The minor ion at $m / z 42$ in Figure $8 b$ has about the same relative intensity in Figure $8 \mathrm{c}$ and is assigned to $\mathrm{NCO}^{-}$.

Additional experiments were carried out to analyze the decomposition processes using multi-stage CID, $\mathrm{MS}^{N}$, with an ion trap on $[\mathrm{M}-\mathrm{H}]^{-}$ions from minocycline and $\left[M\left(D_{6}\right)-D\right]^{-}$ions from minocycline that had undergone essentially complete H/D exchange in the liquid phase. CID in the ion trap on $[\mathrm{M}-\mathrm{H}]^{-}$at $m / z 456$ gave ions at $m / z 439$ and at 413 in about a $1 / 2$ ratio. CID in the ion trap on $\left[\mathrm{M}\left(\mathrm{D}_{6}\right)-\mathrm{D}\right]^{-}$at $m / z 461$ gave ions at $\mathrm{m} / \mathrm{z} 441$ and 417 in the same ratio. Consequently, the neutral molecules lost are $\mathrm{NH}_{3}\left(\mathrm{ND}_{3}\right)$ and $\mathrm{HNCO}$ (DNCO). Ions at $m / z 371$ (373) in these CID spectra were shown to result from decomposition of the ions at $\mathrm{m} / \mathrm{z}$ 439 (441).

There are several possible sites of de-protonation in minocycline whose relative acidities can be roughly estimated from data on simple compounds. Table 2 shows gas phase acidities for anions of simple molecules. These acidities represent heterolytic bond dissociation energies, $\mathrm{D}\left(\mathrm{R}^{-}-\mathrm{H}^{+}\right)$: The larger $\mathrm{D}\left(\mathrm{R}^{-}-\mathrm{H}^{+}\right)$, the stronger the anion is as a base and the weaker the neutral compound is as an acid. The acidities are all large and roughly similar. However, it is likely that the dominant $[\mathrm{M}-\mathrm{H}]^{-}$ion is formed by removal of the phenolic proton at $\mathrm{C}-10$. In Table 2 , the acidities of the phenolic anions are $60-70 \mathrm{~kJ} / \mathrm{mol}$ lower than the acidities of the other oxygenated anions and about 45 $\mathrm{kJ} / \mathrm{mol}$ lower than the acidity of the acetamide anion. Using the difference in gas phase acidities of the anions, $\left(\Delta \Delta G^{o}\right)$, to estimate the relative populations at the different sites from the expression, $\exp \left(-\Delta \Delta \mathrm{G}^{\mathrm{o}} / \mathrm{RT}\right)$, one can estimate that species deprotonated at the phenolic site is $\sim 10^{12}$ times as abundant as species deprotonated at any other hydroxyl site and $\sim 10^{8}$ as abundant as species deprotonated at the amide site. The 


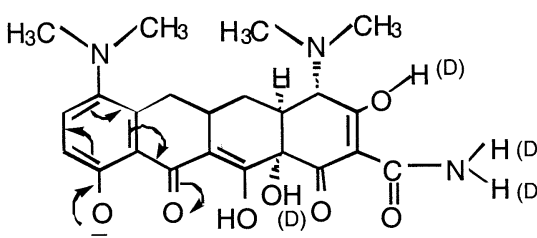

$456(461)$

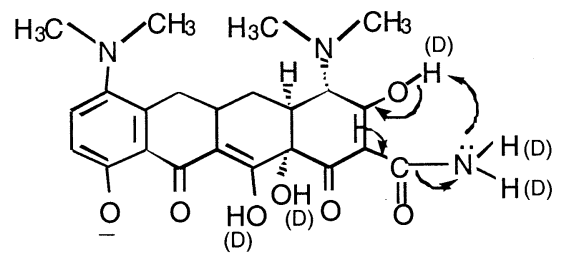

$456(461)$

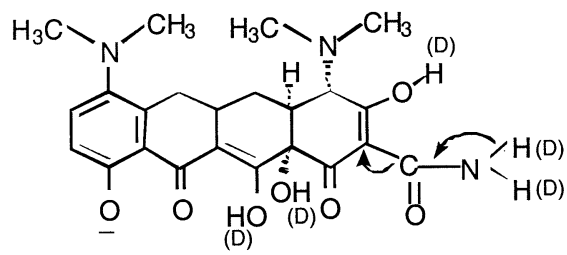

$456(461)$

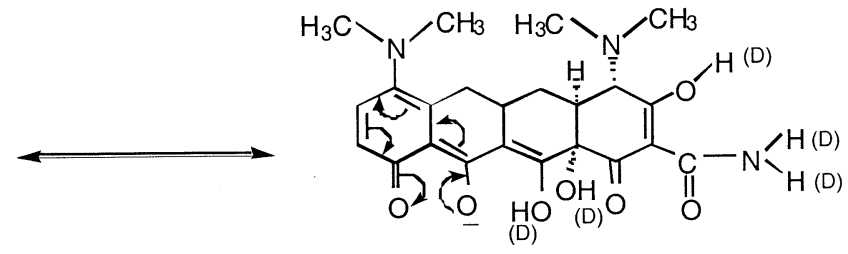

$456(461)$<smiles>CN(C)c1ccc([O-])c2c1CC1C[C@H]3[C@H](N(C)C)C(=O)C(=O)C(=O)[C@@]3(O)C(O)=C1C(=O)C2=O</smiles>

$439(441)$<smiles>[CH]C1=C(O)[C@@H](N(C)C)[C@@H]2CC3Cc4c(N(C)C)ccc([O-])c4C(=O)C3=C(O)[C@]2(O)C1=O</smiles>

$413(417)$

Scheme 4. Proposed initial reactions and CID fragmentation pathways mechanisms showing the loss of ammonia $\left(\mathrm{NH}_{3}\right.$ and isocyanate (NHCO) from deprotonated minocycline and its fragment ions determined from both $\mathrm{H} / \mathrm{D}$ exchange patterns and ion trap $\mathrm{MS}^{\mathrm{N}}$ experiments. Numbers in parentheses refer to deuterated fragment ions.

ratios are not quantitatively correct, but do indicate overwhelming deprotonation at the phenolic site.

Scheme 4 shows suggested mechanisms for the two major decompositions from the de-protonated species. There are no obvious simple cleavage reactions for the $[\mathrm{M}-\mathrm{H}]^{-}$ions. We have no good way of estimating the heats of these ionic rearrangement decompositions. Intramolecular hydrogen bonding between the hydroxyl hydrogen at C-3 and the amide group is likely and essential for the loss of $\mathrm{ND}_{3}$ from $\left[\mathrm{M}\left(\mathrm{D}_{6}\right)-\mathrm{D}\right]^{-}$ ions of minocycline. Although there may be electronic effects transmitted through the four rings, we have written the reactions as charge-remote decompositions [45].

The CID mass spectra of the non-deuterated/deuterated negative ions at $\mathrm{m} / \mathrm{z} 439$ (441) contain low abundance ions at $m / z 421$ (422), corresponding to the loss of $\mathrm{H}_{2} \mathrm{O}$ (HDO), a charge remote elimination of water, perhaps from a 1,2-elimination between $\mathrm{C}-4 \mathrm{a}$ and C-12a. Slightly larger abundances of product ions are observed at $\mathrm{m} / \mathrm{z} 411$ (413), corresponding to the loss of CO. More abundant product ions are observed at $\mathrm{m} / \mathrm{z}$ 395 (397) by loss of dimethylamino radicals, $\left(\mathrm{CH}_{3}\right) \mathrm{N}$. The most abundant product ions from dissociation of ions at $\mathrm{m} / \mathrm{z} 439$ (441) are observed at $\mathrm{m} / \mathrm{z} 371$ (373). Separate experiments show that the ions at $m / z 371$ (373) are not formed from ions at $\mathrm{m} / \mathrm{z} 395$ and result from a direct decomposition from ions at $\mathrm{m} / \mathrm{z} 439$ (441), corresponding to a loss of $\mathrm{C}_{3} \mathrm{O}_{2}$.

The ions at $m / z 395$ (397) decompose to a small extent to $\mathrm{m} / \mathrm{z} 377$ (378) from the loss of $\mathrm{H}_{2} \mathrm{O}$ (HDO), perhaps from a 1,2-elimination between $\mathrm{C}-4 \mathrm{a}$ and C-12a. Slightly more abundant product ions are observed at $m / z 367$ (369) from loss of CO. The most abundant product ions from CID of ions at $\mathrm{m} / \mathrm{z} 395$ (397) are ions at $m / z 351$ (353) from loss of the second dimethylamino radical.

Table 3 shows the principal dissociation products of five deprotonated tetracyclines. The decomposition processes discussed above are observed for each species. All of the tetracyclines gave ions corresponding to $\left[\mathrm{M}-\mathrm{H}-\mathrm{NH}_{3}-\mathrm{HNCO}-\mathrm{C}_{3} \mathrm{O}_{2}-\mathrm{O}=\mathrm{C}=\mathrm{CH}-\mathrm{NH}\left(\mathrm{CH}_{3}\right)_{2}\right]^{-}$and $\left[\mathrm{M}\left(\mathrm{D}_{6}\right)-\mathrm{ND}_{3}-\mathrm{DNCO}-\mathrm{C}_{3} \mathrm{O}_{2}-\mathrm{O}=\mathrm{C}=\mathrm{CH}-\mathrm{N}\left(\mathrm{CH}_{3}\right)_{2}\right]^{-}$. No abundant products from loss of $\mathrm{Cl}$ or $\mathrm{HCl}$ were observed from deprotonated chlortetracycline. We did not scan low enough in mass to observed $\mathrm{Cl}^{-}$as a product ion.

\section{Conclusions}

Solution and gas phase H/D exchange allowed easy determination of the number of replaceable hydrogens in a series of tetracyclines in both negative and positive ESI spectra. The CID spectra of the $[\mathrm{M}-\mathrm{H}]^{-}$ions were 
simpler than the CID spectra of the $[\mathrm{M}+\mathrm{H}]^{+}$ions, and both gave structurally useful fragment ions. The CID spectra of these tetracyclines can serve as models for the identification of chemically or biologically modified tetracyclines or related compounds. Single stage and multiple stage CID experiments on the $[\mathrm{M}+\mathrm{H}]^{+}$and $[\mathrm{M}-\mathrm{H}]^{-}$ions and the fully exchanged analogs allowed interpretation of some decomposition reactions. Very similar decompositions were observed in positive ion CID for all of the tetracyclines, and also in negative ion CID for these compounds. Although the most basic site in the tetracyclines is the dimethylamino group, the dominant loss processes from $[\mathrm{M}+\mathrm{H}]^{+}$ions at low collision energies are the losses of $\mathrm{NH}_{3}$ or of $\mathrm{H}_{2} \mathrm{O}$ (from the species containing a tertiary HO-group at C-6). These loss processes appear to be charge site decompositions involving replaceable hydrogens rather than carbon-bound hydrogens. In the negative ion mode, losses of ammonia and isocyanate appear to proceed through charge-remote fragmentations.

\section{References}

1. McCloskey, J. A. Methods Enzymol. 1990, 193, 329-338.

2. Hass, G. W.; Giblin, D. E.; Gross, M. L. Int. J. Mass Spectrom. Ion Processes 1998, 172(1-2), 25-46.

3. Adejare, A.; Brown, P. W. Anal. Chem. 1997, 69(8), 1525-1529.

4. Ni, J.; Harrison, A. G. Canad. J. Chem. 1995, 73(11), 1779-1784.

5. Feistner, G. J.; Hsieh, L. L. J. Am. Soc. Mass Spectrom. 1995, 6(9), 836-846.

6. Dookeran, N. N.; Harrison, A. G. J. Am. Soc. Mass Spectrom. 1995, 6(1), 19-26.

7. Cushnir, J. R.; Naylor, S.; Lamb, J. H.; Farmer, P. B. Rapid Commun. Mass Spectrom. 1990, 4(10), 426-431.

8. Hunt, D. F.; McEwen, C. N.; Upham, R. A. Anal. Chem. 1972, 44(7), 1292-1294.

9. Hunt, D. F.; McEwen, C. N.; Upham, R. A. Tetrahedron Lett. 1971, 47, 4539-4542.

10. Henion, J. D. J. Chromatogr. Sci. 1981, 19(2), 57-64.

11. Verma, S.; Pomerantz, S. C.; Sethi, S. K.; McCloskey, J. A. Anal. Chem. 1986, 58(14), 2898-2902.

12. Sethi, S. K.; Smith, D. L.; McCloskey, J. A. Biochem. Biophys. Res. Commun. 1983, 112(1), 126-131.

13. Thevenon-Emeric, G.; Kozlowski, J.; Zhang, Z.; Smith, D. L. Anal. Chem. 1992, 64(20), 2456-2458.

14. Edmonds, C. G.; Pomerantz, S. C.; Hsu, F. F.; McCloskey, J. A. Anal. Chem. 1988, 60(20), 2314-2317.

15. Siegel, M. M. Anal. Chem. 1988, 60(19), 2090-2095.

16. Wang, F.; Tang, X-J. Biochem. 1996, 35(13), 4069-4078.

17. Nielen, M. W. F.; Van de Ven, H. J. F. M. Rapid Commun. Mass Spectrom. 1996, 10(1), 74-81.

18. Kamel, A.; Brown, P.; Munson, B. Proceedings of the 44th ASMS Conference on Mass Spectrometry and Allied Topics; Palm Springs, CA, June, 1997; p 1393.

19. Kamel, A.; Brown, P.; Munson, B. Proceedings of the 44th ASMS Conference on Mass Spectrometry and Allied Topics; Palm Springs, CA, June, 1997; p 1392.
20. Kamel, A.; Brown, P.; Munson, B. Proceedings of the 46th ASMS Conference on Mass Spectrometry and Allied Topics; Orlando, FL, May, 1998; p 777.

21. Lueck, N. E. Book of Abstracts; 219th ACS National Meeting; San Francisco, CA, March, 2000.

22. Jager, M.; Pluckthun, A. Protein Sci. 2000, 9(3), 552-563.

23. Akashi, S.; Naito, Y.; Takio, K. Anal. Chem. 1999, 71(21), 4974-4980.

24. Nemirovskiy, O.; Giblin, D. E.; Gross, M. L. J. Am. Soc. Mass Spectrom. 1999, 10(8), 711-718.

25. Maier, C. S.; Schimerlik, M. I.; Deinzer, M. L. Biochem. 1999, 38(3), 1136-1143.

26. Cheng, X.; Fenselau, C. Int. J. Mass Spectrom. Ion Processes 1992, 122, 109-119.

27. Nibbering, M. M. Adv. Phys. Org. Chem. 1988, 24, 1-55.

28. Hemling, M. E.; Conboy, J. J.; Bean, M. F.; Mentzer, M.; Carr, S. A. J. Am. Soc. Mass Spectrom. 1994, 5(5), 434-442.

29. Oka, H.; Ikai, Y.; Hayakawa, J.; Harada, K; Masuda, K.; Suzuki, M.; Himei, R.; Horie, M.; Nakazawa, H. J. Food Hygienic Soc. Japan 1993, 34(6), 517-523.

30. Oka, H.; Ikai, Y.; Hayakawa, J.; Masuda, K.; Harada, K-I; Suzuki, M.; Martz, V.; Macneil, J. D. J. Agri. Food Chem. 1993, 41(3), 410-415.

31. Oka, H.; Ikai, Y.; Hayakawa, J.; Harada, K.; Asukabe, H.; Suzuki, M.; Himei, R.; Horie, M.; Nakazawa, H.; Macneil, J.D. J. Agri. Food Chem. 1994, 42(10), 2215-2219.

32. Carson, M. C.; Ngoh, M. A.; Hadley, S. W. J. Chromatogr. B: Biomed. Sci. Appl. 1998, 712(1+2), 113-128.

33. Straub, R.; Voyksner, R. D. Proceedings of the 40th ASMS Conference on Mass Spectrometry and Allied Topics; Washington, DC., May, 1992; p 1879.

34. Redig, P; Schmulling, T; Vanonckelen, H. . Plant Physiol. 1996, 112(1), 141-148.

35. Faiss, M.; Strand, M.; Redig, P.; Dolezal, K.; Hanus, J.; Vanonckelen, H.; Schmulling, T. Plant J. 1996, 10(1), 33-46.

36. Rudek, M. A.; March, C. L.; Bauer, K. S.; Pluda, J. M.; Figg, W. D. J. Pharm. Biomed. Anal. 2000, 22(6), 1003-1014.

37. Van Eeckhout, N.; Perez, J. C.; Claereboudt, J.; Vandeputte, R.; Van Peteghem, C. Rapid Commun. Mass Spectrom. 2000, 14(4), 280-285.

38. Lock, C. M.; Chen, L.; Volmer, D. A. Rapid Commun. Mass Spectrom. 1999, 13(17), 1744-1754.

39. Nakazawa, H.; Ino, S.; Kato, K.; Watanabe, T.; Ito, Y.; Oka, H. J. Chromatogr. B: Biomed. Sci. Appl. 1999, 732(1), 55-64.

40. Kamel, A. M.; Brown, P. R.; Munson, B. Anal. Chem. 1999, 71(5), 968-977.

41. Oka, H.; Ito, Y.; Ikai, Y.; Kagami, T.; Harada, K. J. Chromatogr., A 1998, 812(1 + 2)), 309-319.

42. Vartanian, V. H.; Goolsby, B.; Brodbelt, J. S. J. Am. Soc. Mass Spectrom. 1998, 9(10), 1089-1098.

43. Heller, D. N. Proceedings of the 48th ASMS Conference on Mass Spectrometry and Allied Topics; Long Beach, CA., June, 2000, pp 822-823.

44. Kamel, A. M.; Brown, P. R.; Munson, B. Anal. Chem. 1999,71(24), 5481-5492.

45. Adams, J. Mass Spectrom. Rev. 1990, 9(2), 141-186.

46. Hunter, E. P.; Lias, S. G. Proton Affinity Evaluation. In NIST Chemistry WebBook, NIST Standard Reference Database Number 69; Mallard, W. G.; Linstrom, P. J. Eds.; National Institute of Standards and Technology: Gaithersburg, Feb. 2000; (http:// webbok.nist.gov).

47. Keesee, R. G.; Castleman, A. W., Jr. J. Phys. Chem. Ref. Data 1986, 15(3), 1011-1071. 